\title{
Article \\ EU-Funded Projects with Actual Implementation of Renewable Energies in Cities. Analysis of Their Concern for Aesthetic Impact
}

\author{
Núria Sánchez-Pantoja ${ }^{1, *(D)}$, Rosario Vidal ${ }^{1}$ (D) and M. Carmen Pastor ${ }^{2}$ (D) \\ 1 Department of Mechanical Engineering and Construction, GID, Universitat Jaume I, Av. Sos Baynat s/n, \\ 12071 Castelló, Spain; vidal@uji.es \\ 2 Department of Basic and Clinical Psychology, and Psychobiology, Universitat Jaume I, Av. Sos Baynat s/n, \\ 12071 Castelló, Spain; mpastor@uji.es \\ * Correspondence: nbelengu@uji.es; Tel.: +34-964-729-252
}

Citation: Sánchez-Pantoja, N.; Vidal, R.; Pastor, M.C. EU-Funded Projects with Actual Implementation of Renewable Energies in Cities. Analysis of Their Concern for Aesthetic Impact. Energies 2021, 14, 1627. https://doi.org/10.3390/ en14061627

Academic Editor: David Borge-Diez

Received: 7 February 2021

Accepted: 11 March 2021

Published: 15 March 2021

Publisher's Note: MDPI stays neutral with regard to jurisdictional claims in published maps and institutional affiliations.

Copyright: (c) 2021 by the authors. Licensee MDPI, Basel, Switzerland. This article is an open access article distributed under the terms and conditions of the Creative Commons Attribution (CC BY) license (https:/ / creativecommons.org/licenses/by/ $4.0 /)$.

\begin{abstract}
Social acceptance and aesthetic impact of renewable energy (RE) in cities are topics scarcely considered in the literature even though they have attracted growing interest. Innovative Europeanfunded projects, therefore, should start to consider these concepts. This paper provides an innovative review of European projects with the aim of identifying those with actual implementation of RE and energy storage systems in urban environments and their concern for aesthetic impact. The search considered the five most relevant programs related to RE and climate change mitigation, including almost 14,000 projects. Furthermore, a survey and some interviews allowed to collect data about the selected projects. $0.1 \%$ of reviewed projects aimed at the actual installation of RE on an urban scale. However, there is a recent growing trend. The most used RE was solar, especially photovoltaic, while the most common system for energy storage was lithium batteries. We can affirm that these European projects do not currently show any particular concern for the aesthetic impact they cause in cities, nor for the social perception assessment. It would be advisable to consider technologies as products and basic components of work and daily life, and not only as a means of intervention to promote RE.
\end{abstract}

Keywords: aesthetic impact; solar energy systems; renewable energies; European projects; urban integration

\section{Introduction}

The fight to reduce the consequences of climate change has fostered implementation of renewable energies [1-4]. First, renewable energy was in rural environments in the form of wind farms, photovoltaic plants, or biomass plants, among others. Then, it was in urban environments, especially using solar energy systems in buildings (both thermal and photovoltaic) [5]. Research on the use of solar energy in buildings was very technical in the early years. The focus of interest was on optimization of the installation from the point of view of energy efficiency [6-10] and the economic costs [11-14]. However, the integration of these technologies in the city is directly related to architecture, and consequently, not only optimization and cost are important, but aesthetics are an added factor that must be considered. In this sense, the focus in this line of work has moved in the last decade to a more social approach, and aesthetic perception analysis began to be slowly introduced into this field of study. Several examples mention the aesthetic impact produced by solar energy systems in buildings and specifically the use of Building Integrated Photovoltaic systems, more known as BIPV systems. BIPV systems are those fully integrated into the envelope of the building as another construction material of the enclosure. For example, the social aesthetic perception of solar systems used in the solar house prototypes displayed during the Solar Decathlon Europe 2014 competition has been assessed [5]. We also found studies 
focusing on methods to evaluate the impact of PV applications [15-17]. Other researchers analyze the social acceptance of these installations $[18,19]$. Several studies have aimed to identify consumer preferences. [20-22], whereas some recent research has focused on the aesthetic integration of BIPV systems in heritage buildings [23,24].

On the other hand, the complexity of implementing energy models based exclusively on renewable energy systems has been emphasized by research in recent years. The main cause is that these energies generally depend on variable weather conditions, such as the sun or the wind, and therefore, it is not possible to guarantee a stable energy supply $[25,26]$. It is not enough to build renewable energy plants or to be self-supplied with solar panels on the building itself. The energy transition requires the implementation of renewable energies on a neighborhood scale, also including energy storage systems (ESS) $[27,28]$.

Considering that the literature review revealed references to research into the social acceptance and aesthetic impact of the integration of renewable energies in cities, it conveyed that these concepts should be considered by innovative European projects in this field. In fact, the purpose of this work is to analyze if the European projects that have served, or currently serve, real implementation of renewable energy systems (RES) with ESSs in the urban environments are concerned about the aesthetic impact they produce, and for the social aesthetic perception. To make it easier, we refer to these projects throughout the article as "Urban Renewable Implementation Projects" (URIPs). Firstly, a literature review has been done, with special attention to the integration of renewable energies in the city, the social acceptance, the aesthetic impact, and the political frame related. The aim is to highlight the importance of the aesthetic impact of installations in the energy transition process, as well as to establish the policy framework related to this research. Afterward, an exhaustive inspection of European-funded projects from the most relevant programs in the field of renewable energies and climate change was carried out to identify those considered as URIPs. The finding of this study led us to affirm that European projects with urban renewable energies implementation do not currently show any particular concern for the aesthetic impact they cause in the city, nor for the evaluation of the aesthetic perception of the affected society. It would be advisable that calls for funding research projects start to consider technologies as products and basic components of work and daily life, and not only as a means of intervention to promote cleaner and renewable energies that help us to preserve the planet.

\section{Literature Review}

This research focuses on whether URIPs are concerned with the aesthetic impact they produce (without assessing the aesthetics of the projects). The aesthetic impact is not usually addressed in the literature related to these projects or to the promotion of the energy transition. However, there is interesting related literature that should be highlighted to better understand the context of the European projects.

Several studies state that projects aimed to promote the implementation of renewable energies on an urban scale and also storage energy systems are of vital importance to effectively combat climate change, to improve global energy performance in cities, and to achieve more resilient cities [26,29-31]. In this sense, terms such as "sustainable communities", "energy autonomy" or "energy self-sufficiency" were already used to speak about sustainable development as a whole, including the technical challenge and the social and political consequences [32].

Concurring with the recommendations of the International Renewable Energy Agency's report [28], there is currently a great interest in research that includes solar energy systems (SES) into urban energy systems [26,33-36]. To this extent, other authors suggested that, from the point of view of the electricity grid, a higher storage capacity is needed to mitigate the costs of managing the load variance in the grid that this would entail [37]. Even considering that optimizing the tilt and orientation of PV systems and aggregating the demand of several buildings minimizes storage needs. In this respect, it should be considered that a greater energy storage capacity would imply a greater volume of the 
facilities and, consequently, a greater difficulty for the aesthetic integration in the urban environment. The greatest interest of the literature related to energy storage systems focuses on maximizing renewable resources $[25,26,35,38]$. However, in the last few years, there is a growing need for a more social approach to the issue and for attention to be paid to the aesthetic impact of urban integration of renewable energy systems (RES) and related ESS on citizens, which has generally been overlooked [15,39-41].

In the field of thermal energy, the aesthetic aspect is less important because they are usually buried and do not have a significant visual impact (for a review of district heating and cooling systems, see the work [42]). In this regard, a new concept (i.e., "urban building energy models (UBEM)") was used to refer to a key planning tool for utilities, municipalities, urban planners, and even architects working on campus-level projects [43].

\subsection{Social Acceptance}

The social acceptance of renewable energies has been debated in the literature because of the visual impact they produce on the landscape. Within the social acceptance, three dimensions have been considered: socio-political, community, and market [44]. However, we found studies stating that few studies on the implementation of renewable energies and energy storage included more than one of these three aspects in their respective analytical frameworks [40]. Additionally, the necessary participation and involvement of residents to promote social acceptance of such projects has been highlighted in several studies [19,45-48]. And it must be also considered that full organizational cooperation between government, university, and industry consistently improves consumer perceptions compared to a partial setup of pilot projects [49].

Previous studies $[19,50]$ stated that aesthetic characteristics were, among others, important influential elements in the choice of adopting PV systems. According to another research [51], "acceptance can be empirically distinguished from support". An innovative study in this field was carried out [40], in which the social acceptance of renewable ESS was addressed but did not include any aesthetic impact assessment. At the scale of the building itself, the integration of the storage systems has been considered in several studies [52-54], but as Navarro et al. state in their review [33,34], formal and aesthetic integration into architectural design has not yet been fully developed commercially.

On the other hand, energy transition and climate adaptation have been linked to the concept of resilience in recent research [55,56]. Resilience invites innovative development to ensure continuity of services despite future uncertainties rather than a climate change protection stance [48]. Nevertheless, it would be advisable to understand that aesthetic and social acceptance should be included in the concept of resilience, even though there is no roadmap for evaluation in the literature.

\subsection{Aesthetic Impact}

Social acceptance of RES projects might be influenced by several factors, such as the perception of a clean and renewable source, economic aspects, awareness, education, environmental concern, land use, and others. Currently, the aesthetic impact of the implemented systems has begun to be considered one of the most important factors in social tolerance. In fact, several studies including rural and urban environments have focused on aesthetic perception of SES deployment and its environmental impacts [5,20,57-63]. Furthermore, in urban environments, the visual appearance of the RES seems very important for the end user's preferences $[15,21]$. Overall, taking into account the visual impact caused in the city by the implementation of renewable energy seems certainly imperative [41].

Aesthetic impact is related to visual perception that could influence social acceptance, and its assessment focuses more on physical characteristics. There was a lack of consensus regarding the methods and the relevant physical factors that should be considered when assessing the aesthetic impact of renewable energy systems in the literature [41]. It could be even stated that there is no experimental literature in which ESSs are also included. In recent research, a methodological framework to assess the aesthetic impact of solar 
energy systems (SES), both in rural and urban settings, was proposed [41]. In this methodological framework, "the aesthetic impact is broken down into three subimpacts: land use, which depends on the size and the quality of the landscape; the own solar energy system, which depends on visibility and degree of integration; and Glare, which depends on visibility." However, when BIPV systems are implemented, it does not make any sense considering land use. Instead, simple objective factors such as color, pattern, or shape must be considered since they nuance more complex factors such as the visibility or the degree of integration. In addition, visibility was stated to be a key factor in improving social acceptance in other research [64].

Considering these three subimpacts and the clear influence of the visibility and degree of integration factors, several aspects should be considered for the design of different renewable energy systems. For example, not well-integrated visible solar systems might have a greater aesthetic impact as they affect, to a greater or lesser extent, the three subimpacts. This could be especially applicable for solar thermal systems that have a lower degree of integration with the environment because of their water tanks. Instead, the aesthetic impact of PV technologies could be reduced by BIPV systems with an appropriate degree of integration (color, modulation, texture, etc.), and by avoiding glare. PV systems in urban public spaces (not in buildings) should be similarly well-integrated into urban furniture to eliminate the subimpact of land use and avoiding glare. On the other hand, biomass boilers or geothermal systems do not have aesthetic impact from visibility, degree of integration, or glare because they are hidden systems with buried conduits. However, it should not be forgotten that these systems do make actual use of the land in the city.

An important factor for the aesthetic impact of renewable energy systems in a city would be visibility. It should be borne in mind that in rural environments, the visibility of windmills has been shown to affect the attitude of the observer $[65,66]$. Additionally, "attitudes play an important role in addition to visual aesthetics in determining the acceptance of windmills and the resulting noise annoyance" [65]. Similarly, the attitude towards a visible PV system might play an important role in determining acceptance and the resulting discomfort with glare, if any. Further studies specifically focused on the observer's attitude may be interesting future research and also consider the possible impact on cultural heritage [66].

Certain similarities are seen in the difficulties integrating the water tanks of solar thermal systems aesthetically compared to implementing energy storage systems. However, the use of either renewable energies or energy storage systems, even when they are an essential part of energy and ecological transition, inevitably entails an aesthetic impact in the city that cannot be ignored. Similarly, researchers should not ignore that urban environments need available public space to implement innovative solutions that improve energy management from a collective point of view. Land use, visibility, and degree of integration seem to be determining factors in the aesthetic impact of these systems. Special attention should be given to location selection to minimize the impact on land use, reducing the size and visibility of the storage systems, and avoiding quality urban spaces. Aesthetic integration will require considering aspects, such as color, texture, or shape, in the design process. In this case, it does not seem relevant to consider the subimpact of glare for the storage systems. Nevertheless, the usual trend when implementing renewable energies still seems to be hiding the installed systems inside the buildings or even burying them, which is not always possible.

\subsection{Political Frame}

In 2009 [67] a common framework for the promotion of energy from renewable sources was established. The EU was the first to set ambitious energy and climate targets: $20 \%$ greenhouse gas emission reduction, $20 \%$ in renewable energy, and $20 \%$ energy efficiency.

A key measure of the Directive was the establishment of mandatory targets and measures for the use of energy from renewable sources for each Member State [68]. Every Member State had to adopt a standardized National Renewable Energy Action Plan 
(NREAP), submit it to the European Commission, and review it every two years. In the NREAPs the Member States had to provide a detailed roadmap on how to reach their 2020 target for the share of renewable energies. As a result of the freedom regarding support instruments to foster renewables, a variety of support schemes for renewables in general and solar energy, in particular, exists across EU Member States and some problems were highlighted in some countries [69] such as policy risk by retroactive and frequent changes of support systems and limited benefits of self-consumption.

The Paris Agreement [70] sets out a global framework to avoid dangerous climate change by limiting global warming to well below $2{ }^{\circ} \mathrm{C}$ and pursuing efforts to limit it to $1.5^{\circ} \mathrm{C}$. The EU formally ratified the agreement on 5 October 2016 , thus enabling its entry into force on 4 November 2016 [71].

With the Paris Agreement, the EU was pledged to move further ahead and achieve greenhouse gas emission reductions of at least $40 \%$ by 2030 . In order to achieve the European Union's 2030 targets, the European Commission presented the Clean Energy for All Europeans package [4]. It includes a new binding renewable energy target for 2030 of at least $32 \%$. The new rules establish that each country will decide how it contributes to these EU objectives by drafting a National Energy and Climate Plan (NECP) for 2021-2030. The draft plans will be evaluated by the European Commission in order to ensure that the EU can collectively meet its Paris Agreement commitments. The national plans also require EU countries to outline a long-term strategy for at least the next 30 years.

Included in the Clean Energy for All Europeans package are the Energy Performance in Buildings Directive (EPBD) and the Energy Efficiency Directive (EED). The direct opportunities for BIPV that these Directives can create are limited, as they focus on energy efficiency and consumption, with no reference to production. Nevertheless, as multifunctional solutions, BIPV systems can also make buildings more energy efficient while producing renewable energy at the same time. On the other hand, the Renewable Energy Directive (RED), wherein "consumers are empowered by enabling them to self-consume without undue restrictions, being remunerated for the electricity they feed into the grid" and the revised Electricity Market Design Regulation and Directive can help to limit the uncertainty linked with the market valuation of the electricity produced by distributed PV system such as BIPV [72].

\section{Materials and Methods}

The method used in this research has two consecutive phases. A first phase aimed to identify the European-funded projects considered as URIPs. In this phase, a systematic search of European projects was conducted. Projects financed with funds from different agencies were searched using a series of filters with three successive steps to select only those projects that met the inclusion criteria established for our study for the URIPs (see Figure 1). In the second phase, additional information on the selected projects were collected. To this aim, an electronic survey was carried out and several interviews were conducted.

\subsection{First Phase Search of Projects}

For the first phase, an online search for funded projects was carried out by focusing on European projects with real application of renewable energy on a neighborhood/district scale. Real application was considered when the project includes the implementation and putting into operation of installations; on the other hand, district or urban scale refers to facilities serving a defined urban area and not a single building. This search was focused on 5 specific programs considered the most relevant to the promotion of renewable energies and climate change mitigation: (1) Interreg is a key instrument of the European Union to fund projects in fields such as health, environment, research, education, and sustainable energy, (2) Climate-KIC is a Knowledge and Innovation Community to support innovative initiatives that help society mitigate and adapt to climate change, (3) the European Life Program funds projects related to the environment and climate action, (4) FP7 was the European Union's Research and Innovation funding program until 2013, and (5) H2020 
is the current European Union's Research and Innovation funding program see Table 1. Projects meeting any of these conditions were excluded from our research: (i) aimed to improve the network, (ii) were located in rural environments or the sea, or (iii) projects in which energy was used for mobility or specific buildings (self-consumption). All projects written in English, Spanish, German, French, Italian, and Portuguese were fully inspected, whereas only keywords were checked for those written in other languages, such as Polish, Czech, or Croatian. The overall methodology followed in our research is summarized in Figure 1, and the two phases of the study are described (i.e., the three filtering steps besides the follow-up surveys).

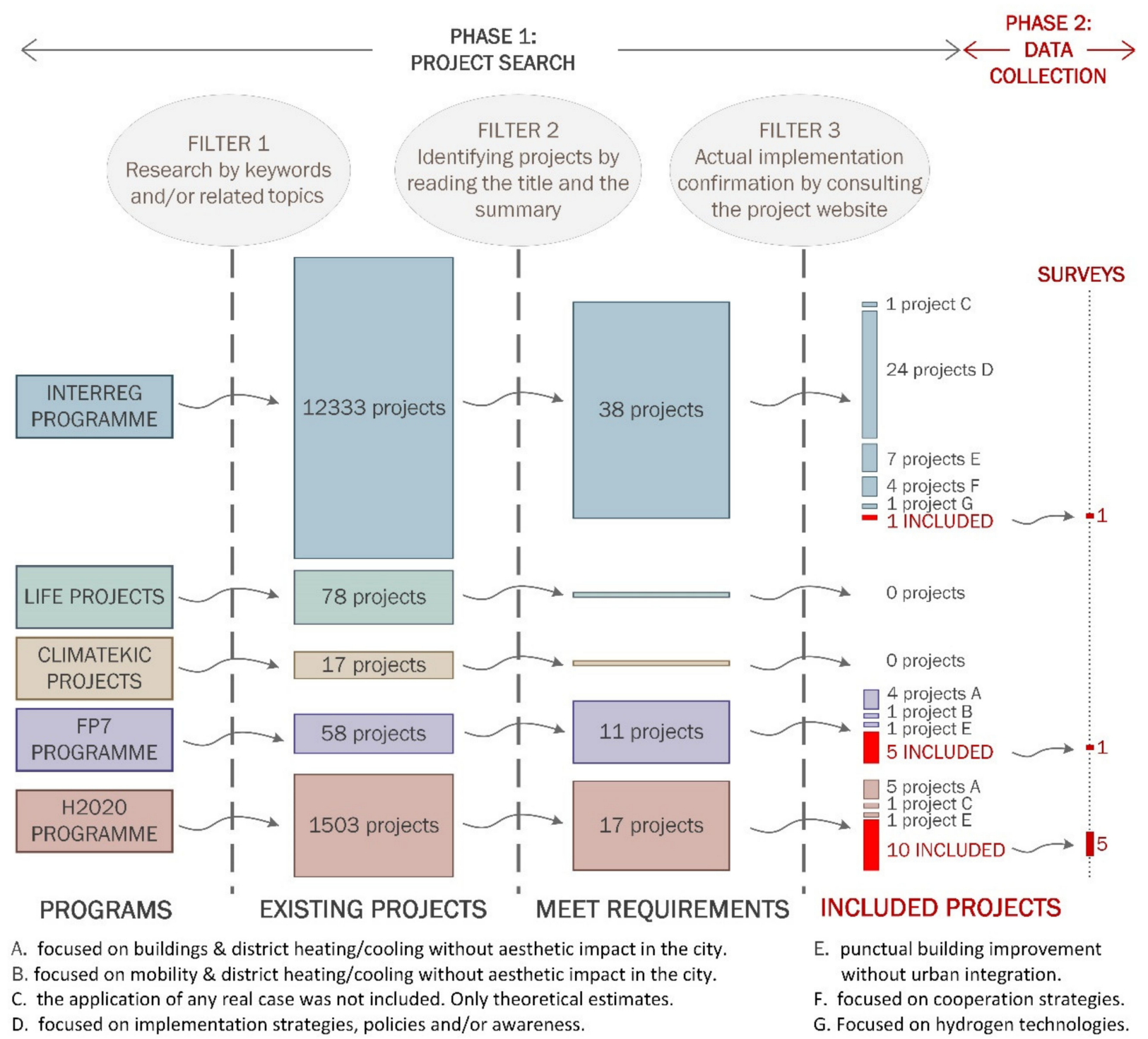

Figure 1. Method of the research carried out in two phases. Phase 1: application of three successive filters to identify the URIPs. Phase 2: data collection through a survey. Letters A to G: reasons for rejecting a project in phase 2.

The first filter was focused on the overall website of the five EU programs. Each program had its own organized project database, so the search method had to be adapted in each case to the structure of the program at the time of the search. Table 1 shows, for each Program, the review method used in its particular website (by topics, by keywords, etc.) and, in the last column, the selected options during the search. For example, the projects included in Interreg program were organized by geographical areas, and the search could be done by specific topics. In this vine, topics listed in Table 1 were activated in the search 
carried out during this first screening phase. Regarding the website of the Life program, however, the search could be done by choosing different strands. In the case of ClimateKic, the website offered the possibility of using keywords that facilitated the search. Finally, funded projects were organized by domains in the FP7-Energy and H2020 programs, the latter also having specific lines. Combining the 5 programs (i.e., Interreg, Life, Climate-KIC, FP7, and H2020), a total of 13,989 projects were examined in the first screening.

Table 1. Main information of the filter 1 applied to online search for European-funded project. Databases visited in September 2018.

\begin{tabular}{|c|c|c|c|}
\hline Program & Database/Platform & Review Method & $\begin{array}{c}\text { Keywords/Topics/Strands/Domains } \\
\text { (Filter 1) }\end{array}$ \\
\hline Interreg & https://interreg.eu/ & Projects organized by topics & $\begin{array}{c}\text { Low-carbon economy } \\
\text { Combating climate change } \\
\text { Environment and resource efficiency }\end{array}$ \\
\hline Life & $\begin{array}{l}\text { https: } \\
\text { / /ec.europa.eu/easme/en/life }\end{array}$ & Projects organized by strands & $\begin{array}{c}\text { Climate change adaptation } \\
\text { Climate change mitigation } \\
\text { Energy }\end{array}$ \\
\hline ClimateKic & $\begin{array}{l}\text { https: } \\
\text { / / www.climate-kic.org/projects / }\end{array}$ & Search by keywords & $\begin{array}{l}\text { Renewable energy } \\
\text { Urban energy storage } \\
\text { Energy transition } \\
\text { Cities development }\end{array}$ \\
\hline FP7-Energy & https://cordis.europa.eu/ & Projects organized by domains & $\begin{array}{l}\text { All projects included in the domain } \\
\text { "Energy" of the Program } \\
\text { "FP7-Energy" }\end{array}$ \\
\hline \multirow[b]{2}{*}{ H2020-EU.3.3.1 } & $\begin{array}{c}\text { https: } \\
\text { / / cordis.europa.eu/search/en }\end{array}$ & \multirow{2}{*}{$\begin{array}{l}\text { Projects organized by } \\
\text { domains and specific lines }\end{array}$} & $\begin{array}{l}\text { All projects included in the domain } \\
\text { "Energy" of the Program "H2020" }\end{array}$ \\
\hline & $\begin{array}{l}\text { https:/ /ec.europa.eu/easme/en/ } \\
\text { section/energy/intelligent- } \\
\text { energy-europe }\end{array}$ & & $\begin{array}{l}\text { All projects included in the line } \\
\text { "Intelligent Energy Europe (IEE)" }\end{array}$ \\
\hline
\end{tabular}

In the second filtering step, the title and summary of each project were read to identify those related to the implementation of renewable energies on an urban scale. As a result, 38 projects from the Interreg Program, 11 from FP7-Energy, and 17 from the H2020 Program were selected because they were related to the main topic.

In the third filtering step, the websites of these 66 projects were consulted to confirm whether the selected projects included real implementation of renewable energies on an urban scale. Sections such as publications, newsletter, events, or deliverables were analyzed looking for information and/or pictures that would evidence the actual implementation of renewable energy installations on an urban scale. After applying this last filter, a total of 16 European projects were selected for the survey conducted in the second phase of the study. The rest of the projects were discarded for meeting any of the following exclusion criteria:

A. focused on buildings and district heating/cooling without aesthetic impact in the city, B. focused on mobility and district heating/cooling without aesthetic impact in the city, C. the application of any real case was not included, only theoretical estimates,

D. focused on implementation strategies, policies, and/or awareness,

E. punctual building improvements and not urban integration,

F. focused on cooperation strategies,

G. focused on hydrogen technologies.

\subsection{Second Phase. Data Collection}

The second phase of our study consisted of collecting additional information on the 16 URIPs. The information should allow us to know the main features of the installations 
in order to get an impression of the type of impact they could have on the affected area and its magnitude. To this aim, a short survey was designed (see Supplementary Materials) with specific questions about the facility features implemented throughout each project, including information about the specific type of renewable energy system and storage energy system implemented, surfaces, efficiency, etc. Respondents could select from thermal solar, PV, wind energy, biofuels, hydroelectric power, geothermal energy, wave power or specify another option for renewable energy systems. Regarding the storage systems, they could choose from pumped hydro storage, compressed air energy storage, flywheels, supercapacitors, redox flow batteries, lithium batteries, hydrogen storage or specify another option. The content of the questions was validated with a group of experts from the Energy Engineering Institute at the Polytechnic University of Valencia (Spain).

The first contact with the person responsible for each project inviting them to participate in the research was made via email during the month of November 2018, and the data collection process was carried out until mid-January 2019. This process was rather complex because almost $70 \%$ of the projects were not yet completed at the time. Additionally, many contacts were reluctant to share data from funded projects since the majority were under development or only had preliminary estimates. In some cases, the person who answered the survey claimed that they did could not provide the data required in the survey or they did not get a response from consortium members allowing them to do so. Therefore, certain information was difficult to collect as several entities were unwilling or unable to participate by providing relevant data. At the end of the survey process, a series of interviews (via email or telephone) were conducted by the first author to find out the concerns of the consortium carrying out the project about the aesthetic impact that was occurring. In the data collection process, information could be collected for six European projects, including seven districts as real demonstrations.

\section{Results}

The results are summarized separately for the different programs explored in this study. Table 2 shows the findings for the Interreg program, Table 3 shows FP7, and Table 4 shows the H2020 program. study. The results from Life and Climate-KIC Programs are not shown in tables since no projects were identified as URIP. Overall, low involvement in the real implementation of renewable energies on an urban scale was revealed in European projects by these data.

For each specific area or topic, the above tables show the following information: (a) number of existing projects (Filter 1), (b) how many projects were identified related to the implementation of RES on an urban scale (Filter 2), (c) acronyms, (d) program period to which they belong, and (e) the established inclusion and exclusion criteria (Filter 3). Furthermore, as the Interreg Program was divided into four sub-programs and then into geographic areas, Table 2 shows in the first column the Interreg Sub-program (ISP) to which the geographic area of the second column belongs. These Interreg Sub-programs are: Interregional, Transnational, Pre-Accession Assistance Cross-border Cooperation (IPA CBC) and Cross Border. Eventually, 16 out of 13,989 examined projects met the requirements: 1 project in the Interreg Program (see Table 2), 5 projects in the FP7 Program (see Table 3), and 10 projects in the H2020 Program (see Table 4).

Regarding the LIFE program, the established inclusion criteria were not met by any funded projects. Indeed, all projects were focused on the field of technology development and mainly applied to mobility issues. As far as buildings, only funded projects for specific public buildings were found in our search. Nothing was found on an urban scale.

For the Climate-KIC program, the search was carried out using keywords: renewable energy/ies, urban energy storage, energy transition, and city development. Unfortunately, no research project that applied renewable energies on an urban scale was found. 
Table 2. Results for projects corresponding to the Interreg Program. The first column corresponds to the Interreg SubProgram (ISP) to which the geographic area of the second column belongs: interregional (IN), transnational (TR), IPA CBC (IC) and cross Border (CB).

\begin{tabular}{|c|c|c|c|c|c|c|}
\hline ISP & \multicolumn{2}{|c|}{ Area/Number Projects Revised in the Area } & \multirow{2}{*}{$\begin{array}{c}\begin{array}{c}\text { Identified } \\
\text { Projects }\end{array} \\
1\end{array}$} & \multirow{2}{*}{$\begin{array}{l}\text { Acronym } \\
\text { RENERGY }\end{array}$} & \multirow{2}{*}{$\begin{array}{c}\text { Program Period } \\
2007-2013 \\
\end{array}$} & \multirow{2}{*}{$\begin{array}{c}\begin{array}{c}\text { Reason for } \\
\text { Noninclusion }\end{array} \\
\text { D }\end{array}$} \\
\hline IN & Europe & 204 & & & & \\
\hline \multirow{2}{*}{ TR } & \multirow{2}{*}{$\begin{array}{l}\text { ADRION (Adriatic } \\
\text { Ionian) }\end{array}$} & \multirow[b]{2}{*}{65} & \multirow[b]{2}{*}{2} & SEA-R & 2007-2013 & $\mathrm{D}$ \\
\hline & & & & Adriacold & $2007-2013$ & $\mathrm{D}$ \\
\hline TR & Alpine Space & 49 & 0 & None & & \\
\hline TR & Atlantic Area & 70 & 0 & None & & \\
\hline TR & Baltic Sea Region & 19 & 0 & None & & \\
\hline \multirow{4}{*}{$\mathrm{TR}$} & \multirow{4}{*}{ Central Europe } & \multirow{4}{*}{209} & \multirow{4}{*}{4} & ENERGYREGION & $2007-2013$ & $\mathrm{D}$ \\
\hline & & & & EnSURE & $2007-2013$ & $\mathrm{D}$ \\
\hline & & & & $\mathrm{CoP}$ & $2007-2013$ & $\mathrm{D}$ \\
\hline & & & & CEC5 & $2007-2013$ & E \\
\hline TR & Indian Ocean & 15 & 0 & None & & \\
\hline TR & Mediterranean & 159 & 0 & None & & \\
\hline TR & North Sea Region & 148 & 1 & North Sea-SEP & 2007-2013 & $\mathrm{D}$ \\
\hline \multirow[b]{2}{*}{$\mathrm{TR}$} & \multirow[b]{2}{*}{ Northwest Europe } & \multirow[b]{2}{*}{55} & \multirow[b]{2}{*}{2} & GenComm & 2014-2020 & G \\
\hline & & & & HeatNet NWE & $2016-2020$ & INCLUDED \\
\hline TR & SUDOE & 36 & 0 & None & & \\
\hline $\mathrm{TR}$ & $\begin{array}{l}\text { Northern Periphery and } \\
\text { Arctic }\end{array}$ & 86 & 0 & None & & \\
\hline IC & $\begin{array}{l}\text { Bulgaria-The Former } \\
\text { Yugoslav Republic of } \\
\text { Macedonia }\end{array}$ & 70 & 1 & $\begin{array}{c}\text { Cross-border } \\
\text { cooperation in the } \\
\text { field of RE } \\
\text { Sources and } \\
\text { Energy Efficiency }\end{array}$ & 2007-2013 & $\mathrm{F}$ \\
\hline IC & Bulgaria-Turkey & 63 & 0 & None & & \\
\hline IC & $\begin{array}{l}\text { Greece-The former } \\
\text { Yugoslav Republic of } \\
\text { Macedonia }\end{array}$ & 38 & 1 & PEEBPE & 2007-2013 & E \\
\hline IC & Romania-Serbia & 48 & 1 & $\begin{array}{c}\text { Energy } \\
\text { Efficiency-The } \\
\text { Premise of a } \\
\text { Better } \\
\text { Environment }\end{array}$ & 2014-2020 & E \\
\hline IC & Hungary-Serbia & 203 & 0 & None & & \\
\hline $\mathrm{CB}$ & Vlaanderen-Nederland & 193 & 0 & None & & \\
\hline $\mathrm{CB}$ & $\begin{array}{l}\text { V-A Hungary-Croatia } \\
\text { Coop. Progr. }\end{array}$ & 162 & 0 & None & & \\
\hline $\mathrm{CB}$ & Sweden-Norway & 376 & 0 & None & & \\
\hline $\mathrm{CB}$ & South Baltic & 135 & 0 & None & & \\
\hline $\mathrm{CB}$ & Slovenia-Hungary & 11 & 0 & None & & \\
\hline $\mathrm{CB}$ & Slovenia-Croatia & 20 & 0 & None & & \\
\hline $\mathrm{CB}$ & Slovenia-Austria & 139 & 0 & None & & \\
\hline $\mathrm{CB}$ & Slovakia-Hungary & 59 & 0 & None & & \\
\hline $\mathrm{CB}$ & $\begin{array}{l}\text { Slovakia-Czech } \\
\text { Republic }\end{array}$ & 280 & 0 & None & & \\
\hline $\mathrm{CB}$ & Slovakia-Austria & 107 & 0 & None & & \\
\hline
\end{tabular}


Table 2. Cont

\begin{tabular}{|c|c|c|c|c|c|c|}
\hline ISP & Area/Number Projects Re & n the Area & $\begin{array}{l}\text { Identified } \\
\text { Projects }\end{array}$ & Acronym & Program Period & $\begin{array}{c}\text { Reason for } \\
\text { Noninclusion }\end{array}$ \\
\hline \multirow{2}{*}{$\mathrm{CB}$} & \multirow{2}{*}{ Romania-Hungary } & \multirow{2}{*}{662} & \multirow{2}{*}{2} & Geotherm & 2007-2013 & $\mathrm{D}$ \\
\hline & & & & GEO THERMIC & $2007-2013$ & $\mathrm{D}$ \\
\hline $\mathrm{CB}$ & Romania-Bulgaria & 152 & 0 & None & & \\
\hline CB & $\begin{array}{c}\text { Rhin } \\
\text { supérieur-Oberrhein }\end{array}$ & 39 & 0 & None & & \\
\hline $\mathrm{CB}$ & Poland-Slovakia & 7 & 0 & None & & \\
\hline $\mathrm{CB}$ & $\begin{array}{c}\text { Poland- } \\
\text { Germany/Saxony }\end{array}$ & 142 & 0 & None & & \\
\hline \multirow{2}{*}{$\mathrm{CB}$} & \multirow{2}{*}{$\begin{array}{c}\text { POCTEP } \\
\text { (Spain-Portugal) }\end{array}$} & \multirow{2}{*}{236} & \multirow{2}{*}{2} & \multicolumn{2}{|c|}{ 0317_ALTERCEXA_4_E 2007-2013 } & $\mathrm{D}$ \\
\hline & & & & 0062_RETALER_6_E & 2007-2013 & $\mathrm{D}$ \\
\hline $\mathrm{CB}$ & $\begin{array}{c}\text { POCTEFA } \\
\text { (Spain/France/Andorra) }\end{array}$ & 133 & 0 & \multicolumn{2}{|l|}{ None } & \\
\hline $\mathrm{CB}$ & $\begin{array}{l}\text { Öresund-Kattegat- } \\
\text { Skagerrak }\end{array}$ & 128 & 0 & \multicolumn{2}{|l|}{ None } & \\
\hline CB & $\begin{array}{l}\text { Northern Ireland- } \\
\text { Ireland-Scotland } \\
\text { (UK-Ireland) }\end{array}$ & 87 & 1 & SPIRE & 2007-2013 & $\mathrm{D}$ \\
\hline $\mathrm{CB}$ & $\begin{array}{l}\text { Nord (Sweden-Finland- } \\
\text { Norway) }\end{array}$ & 236 & 0 & None & & \\
\hline $\mathrm{CB}$ & $\begin{array}{l}\text { Madeira-Açores- } \\
\text { Canarias } \\
\text { (MAC) }\end{array}$ & 293 & 1 & ERAMAC-2 & 2000-2006 & $\mathrm{D}$ \\
\hline $\mathrm{CB}$ & Lithuania-Poland & 245 & 0 & None & & \\
\hline \multirow{3}{*}{$\mathrm{CB}$} & \multirow[b]{2}{*}{ Latvia-Lithuania } & \multirow[b]{2}{*}{270} & \multirow[b]{2}{*}{2} & Solar Think Tank & $2007-2013$ & $\mathrm{D}$ \\
\hline & & & & $\begin{array}{l}\text { Renewable } \\
\text { energy }\end{array}$ & 2007-2013 & E \\
\hline & \multirow[b]{2}{*}{ Italy-Switzerland } & \multirow[b]{2}{*}{215} & \multirow[b]{2}{*}{2} & PV-Alps & 2007-2013 & $\mathrm{D}$ \\
\hline $\mathrm{CB}$ & & & & $\begin{array}{l}\text { Innovazione } \\
\text { Energetica }\end{array}$ & 2007-2013 & $\mathrm{D}$ \\
\hline $\mathrm{CB}$ & Italy-Slovenia & 336 & 1 & ENRI & 2007-2013 & E \\
\hline $\mathrm{CB}$ & Italy-Malta & 37 & 1 & RESI & $2007-2013$ & $\mathrm{D}$ \\
\hline $\mathrm{CB}$ & Italy-France & 271 & & None & & \\
\hline $\mathrm{CB}$ & Italy-Austria & 216 & 1 & ALTER VIS & 2007-2013 & $\mathrm{D}$ \\
\hline CB & Ireland-Wales & 41 & 0 & None & & \\
\hline $\mathrm{CB}$ & Greece-Italy & 112 & 0 & None & & \\
\hline $\mathrm{CB}$ & Greece-Cyprus & 82 & 1 & ENЕРГЕIN & $2007-2013$ & $\mathrm{E}$ \\
\hline $\mathrm{CB}$ & Greece-Bulgaria & 114 & 1 & ENERGEIA & 2007-2013 & $\mathrm{C}$ \\
\hline \multirow{2}{*}{$\mathrm{CB}$} & \multirow{2}{*}{$\begin{array}{c}\text { Grande } \\
\text { Région/Großregion }\end{array}$} & \multirow{2}{*}{170} & \multirow{2}{*}{2} & VallEnergie & $2007-2013$ & F \\
\hline & & & & ENEFF & 2007-2013 & $\mathrm{F}$ \\
\hline $\mathrm{CB}$ & $\begin{array}{l}\text { Germany/Saxony- } \\
\text { Czech } \\
\text { Republic }\end{array}$ & 164 & 1 & ENA1 & 2007-2013 & F \\
\hline $\mathrm{CB}$ & $\begin{array}{c}\text { Germany/Bavaria- } \\
\text { Czech } \\
\text { Republic }\end{array}$ & 222 & 0 & None & & \\
\hline $\mathrm{CB}$ & $\begin{array}{l}\text { Germany/Mecklenburg- } \\
\text { Western } \\
\text { Pomerania/Brandenburg- } \\
\text { Poland }\end{array}$ & 190 & 0 & None & & \\
\hline
\end{tabular}


Table 2. Cont.

\begin{tabular}{|c|c|c|c|c|c|c|}
\hline ISP & \multicolumn{2}{|c|}{ Area/Number Projects Revised in the Area } & \multirow{2}{*}{$\begin{array}{c}\begin{array}{c}\text { Identified } \\
\text { Projects }\end{array} \\
0\end{array}$} & \multirow{2}{*}{$\begin{array}{c}\text { Acronym } \\
\text { None }\end{array}$} & \multirow[t]{2}{*}{ Program Period } & \multirow[t]{2}{*}{$\begin{array}{c}\text { Reason for } \\
\text { Noninclusion }\end{array}$} \\
\hline $\mathrm{CB}$ & $\begin{array}{l}\text { Germany/Brandenburg- } \\
\text { Poland }\end{array}$ & 84 & & & & \\
\hline $\mathrm{CB}$ & Germany-Denmark & 206 & 0 & None & & \\
\hline \multirow[b]{3}{*}{$\mathrm{CB}$} & \multirow{3}{*}{$\begin{array}{l}\text { France (Channel) } \\
\text { England }\end{array}$} & \multirow{3}{*}{327} & \multirow[b]{3}{*}{3} & SEACS & $2007-2013$ & $\mathrm{D}$ \\
\hline & & & & ECO FAB 2 & $2007-2013$ & $\mathrm{D}$ \\
\hline & & & & $\begin{array}{l}\text { Affordable } \\
\text { Sustainable } \\
\text { Housing }\end{array}$ & 2000-2006 & $\mathrm{D}$ \\
\hline $\mathrm{CB}$ & $\begin{array}{l}\text { France-Wallonie- } \\
\text { Vlaanderen }\end{array}$ & 202 & 1 & $\begin{array}{l}\text { Sustainable } \\
\text { Energy } \\
\text { Management }\end{array}$ & 2007-2013 & $\mathrm{E}$ \\
\hline $\mathrm{CB}$ & France-Switzerland & 218 & 1 & $\begin{array}{c}\text { Les énergies } \\
\text { renouvelables au } \\
\text { service du } \\
\text { développement } \\
\text { durable }\end{array}$ & 2000-2006 & $\mathrm{D}$ \\
\hline $\mathrm{CB}$ & Estonia-Latvia & 150 & 0 & None & & \\
\hline \multirow[b]{2}{*}{$\mathrm{CB}$} & \multirow[b]{2}{*}{ DE-NL } & \multirow[b]{2}{*}{705} & \multirow[b]{2}{*}{2} & $\begin{array}{c}\text { Energie ohne } \\
\text { Grenzen-II-04 = } 097\end{array}$ & 2007-2013 & $\mathrm{D}$ \\
\hline & & & & $\begin{array}{l}\text { Cleantech Energy } \\
\text { Crossing }\end{array}$ & 2014-2020 & $\mathrm{D}$ \\
\hline $\mathrm{CB}$ & Czech Republic-Poland & 726 & 0 & None & & \\
\hline $\mathrm{CB}$ & Central Baltic & 219 & 0 & None & & \\
\hline $\mathrm{CB}$ & Botnia-Atlantica & 64 & 0 & None & & \\
\hline $\mathrm{CB}$ & Austria-Hungary & 133 & 0 & None & & \\
\hline $\mathrm{CB}$ & Austria-Germany & 125 & 0 & None & & \\
\hline $\mathrm{CB}$ & Austria-Czech Republic & 604 & 0 & None & & \\
\hline $\mathrm{CB}$ & $\begin{array}{c}\text { Alpenrhein-Bodensee- } \\
\text { Hochrhein } \\
\text { (DE/AT/CH/FL) }\end{array}$ & 225 & 0 & None & & \\
\hline $\mathrm{CB}$ & $\begin{array}{c}\text { ALCOTRA } \\
\text { (France-Italy) }\end{array}$ & 417 & 0 & None & & \\
\hline \multirow[t]{2}{*}{$\mathrm{CB}$} & 2 Seas & 109 & 0 & None & & \\
\hline & Total Projects: & 12,333 & 38 & & & \\
\hline
\end{tabular}

Specifically, for the Interreg Program (see Table 2), certain projects focused on strategy development or policies designed to encourage the implementation of RE, such as the Low carbon (plan) project, were found. Projects focused on punctual integration of RES within buildings were also found, but these projects were discarded because they did not carry out real implementation on an urban scale.

Concerning the EU FP7-Energy Program (see Table 3), the European projects browser, cordis.europa.eu, was used to search for projects, choosing the domain "Energy". The FP7 call contained many projects meeting the criteria established for the search, but the overall requirements were met only by a few. Thus, some projects were focused on the improvement of existing buildings or the construction of new efficient buildings. However, they were not able to act at the district or neighborhood level (e.g., NEED4B, E2REBUILD, EU-GUGLE, etc.). In addition, the Pitagoras, Sinfonia, and Flexinets projects, among others, improved heating or cooling systems at the district level, but recovery of residual heat does not require an aesthetic integration of the installation at an urban level. Therefore, such projects were also excluded from this study. 
Table 3. Results for Projects Corresponding to the FP7 Program.

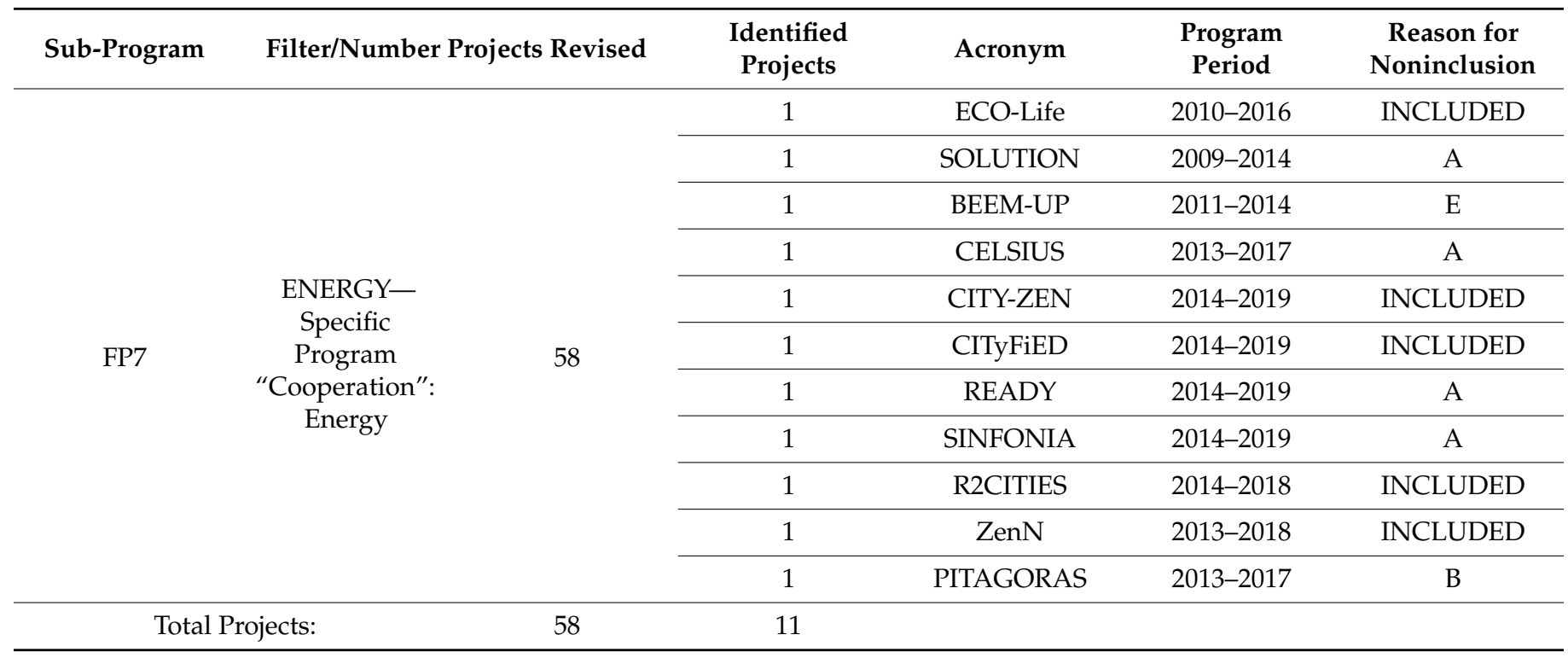

Table 4. Results for projects corresponding to the H2020 program.

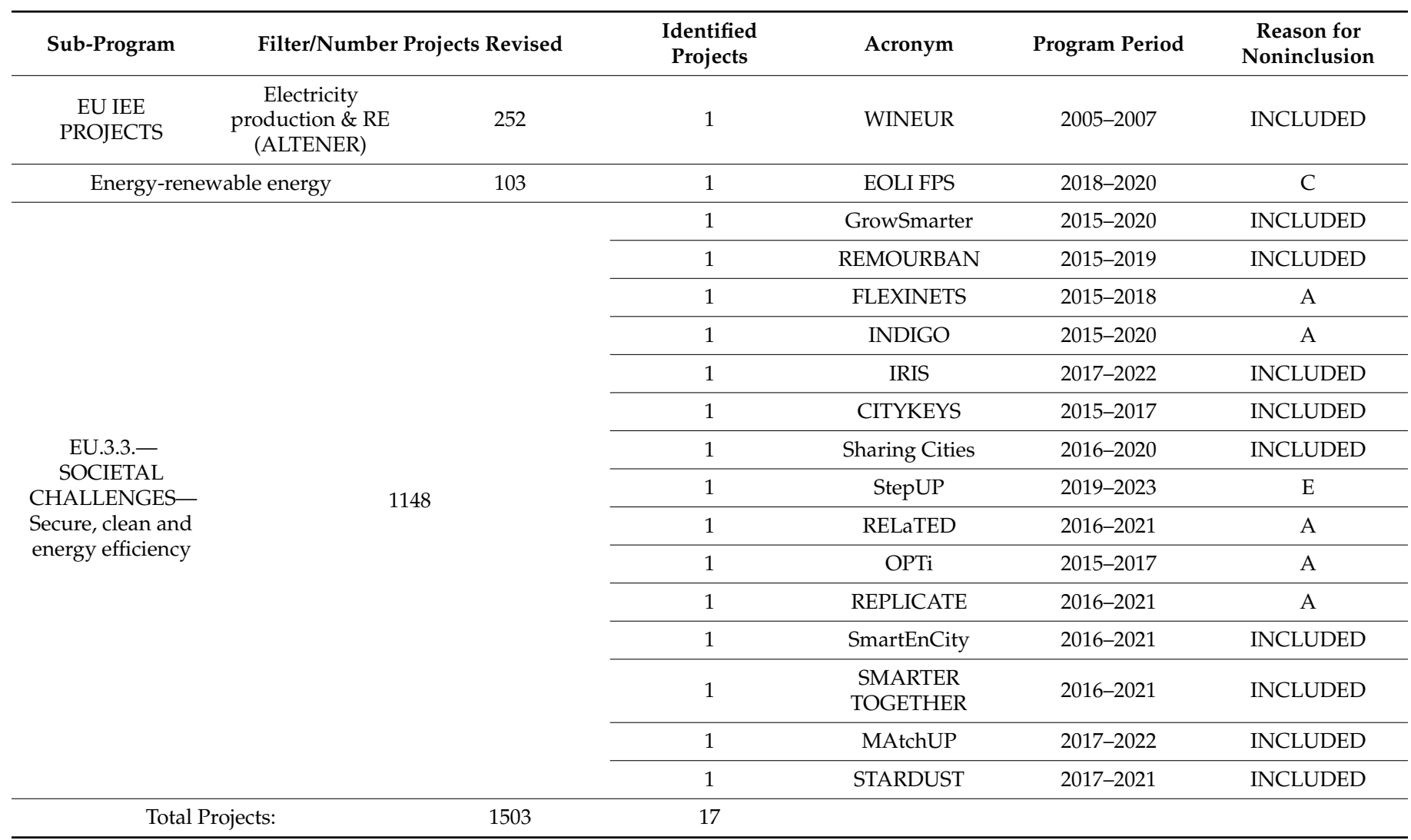

Finally, for the EU H2020 Program (see Table 4), the same browser, cordis.europa.eu, was also used in the search. In particular, projects that met the criteria defined a priori in our study were included by the H2020-UE.3.3 research line. However, most of the examined projects focused on new technology development (e.g., SWInG, FlexHyJoin, CHEOPS, INCOVER), monitoring, management, and optimization of installations (e.g., SYMBIOPTIMA, MOSES, OPTi, TOPAs), or energy efficiency improvement and low consumption, without acting at the community level but building to building (e.g., REnnovates, TRANSITION 
ZERO, REFURB, NewTREND). In addition, for the Intelligent Energy Europe (IEE) research line in the H2020 Program, a large number of funded projects focused on biofuels or in collective heating and cooling systems were found that were finally dismissed for failing to consider the aesthetic impact on the cities, (e.g., REnnovates, TRANSITION ZERO, REFURB, NewTREND). For this reason, the complete requirements in our study were met only by one project from this program.

In summary, as shown in Table 5, the number of European-funded projects aimed at the real and effective implementation of renewable energy systems on an urban scale is relatively low, as only 16 out of 13,989 examined projects (approximately $0.1 \%$ ) meet those criteria or standards.

Table 5. Data from the research on European-funded projects.

\begin{tabular}{ccccc}
\hline & Revised Projects & $\begin{array}{c}\text { Projects } \\
\text { Identified with } \\
\text { Requirements }\end{array}$ & Percentage & $\begin{array}{c}\text { Projects Included } \\
\text { in the Study }\end{array}$ \\
\hline interreg program & 12,333 & 38 & $0.3 \%$ & 1 \\
\hline life projects & 78 & 0 & $0.0 \%$ & 0 \\
\hline climate KIC projects & 17 & 0 & $0.0 \%$ & 5 \\
\hline FP7 program & 58 & 11 & $19.0 \%$ & 10 \\
\hline H2020 program & 1503 & 17 & $1.1 \%$ & 16 \\
\hline total & 13,989 & 66 & $0.5 \%$ & 0 \\
\hline
\end{tabular}

\subsection{Survey Results}

During the data collection process conducted in phase two, the focus was on the 16 selected projects, 11 ongoing projects, and 5 completed projects. Of the ongoing projects, 5 responded to the survey $(45 \%)$, whereas of the completed projects, only 1 responded $(25 \%)$. Of the 16 selected projects, $37 \%$ completed the survey, from which interesting data about the implemented technologies can be reported. Descriptive information regarding the respondents to the survey can be summarized into 6 projects and 7 cities as follows (acronym of the project, city, and country, program period):

ECO-Life-Høje-Taastrup, Denmark. 2010-2016

HeatNET NEW-Boulogne-Sur-Mer, France. 2016-2020 (ongoing project)

Remourban-Nottingham, UK. 2015-2019 (ongoing project)

GrowSmarter-Cologne, Germany. 2015-2020 (ongoing project)

Smarter Together 1-Lyon, France. 2016-2021 (ongoing project)

Smarter Together 2-Munich, Germany. 2016-2021 (ongoing project)

SmartEnCity-Vitoria-Gasteiz, Spain. 2016-2021 (ongoing project).

This quantity of projects might seem irrelevant; however, they represent $38 \%$ of the projects that meet the requirements of the study and, since there are no previous similar studies, the results provide interesting information on the current European framework. For instance, as shown in Table 6, the most implemented RES (71\%) were photovoltaic systems. To a lesser extent, our findings suggest that implementations of solar thermal, biomass and/or geothermal energy systems have been common (43\%) but always accompanied by photovoltaic systems. Wind energy systems were used in a unique project that was already completed and never integrated within the built urban environment. Biofuels and hydroelectric and wave power are systems never used in integration projects on an urban scale. On the other hand, the use of energy storage systems has not been massively widespread ( $43 \%)$ as they are more recent and usually associated with solar energy systems, with lithium batteries as the most common type. Storage systems such as compressed air, flywheels, supercapacitors, redox flow batteries, or hydrogen were never used in any study. In addition, other relevant information such as the price of the energy generated with the installed systems was difficult to obtain through the electronic survey. 
Table 6. Renewable energy systems and energy storage systems used in the projects participating in the survey.

\begin{tabular}{|c|c|c|c|c|c|c|c|c|c|c|c|c|c|c|c|c|}
\hline & \multicolumn{8}{|c|}{ Renewable Energy System Implemented } & \multicolumn{8}{|c|}{ Energy Storage System Used } \\
\hline & TS & PV & WE & Bf & $\mathrm{He}$ & $\mathrm{Gt}$ & WP & Other & PH & CA & $\mathbf{F}$ & SC & RfB & LB & $\mathbf{H}$ & Other \\
\hline ECO-Life & $x$ & $x$ & $x$ & & & $x$ & & & & & & & & & & \\
\hline $\begin{array}{c}\text { HeatNET } \\
\text { NEW }\end{array}$ & & & & & & & & $\begin{array}{l}\text { Cogeneration, } \\
\text { Heat Pump, } \\
\text { Incineration. }\end{array}$ & & & & & & & & \\
\hline Remourban & $x$ & $x$ & & & & $x$ & & & $x$ & & & & & $x$ & & \\
\hline GrowSmarter & & $x$ & & & & & & $\begin{array}{l}\text { Air-Water Heat } \\
\text { pumps }\end{array}$ & & & & & & $x$ & & \\
\hline $\begin{array}{l}\text { Smarter } \\
\text { Together } 1\end{array}$ & $x$ & $x$ & & & & & & Biomass & & & & & & & & $\begin{array}{c}\text { Not done } \\
\text { yet }\end{array}$ \\
\hline $\begin{array}{l}\text { Smarter } \\
\text { Together } 2\end{array}$ & & $x$ & & & & $x$ & & & & & & & & $x$ & & \\
\hline SmartEnCity & & & & & & & & Biomass & & & & & & & & Pellets \\
\hline
\end{tabular}

Abbreviations: TS—Thermal Solar; PV—Photovoltaic; WE—Wind Energy; Bf-Biofuels; He-Hydroelectric; Gt—Geothermal; WP—Wave power; PH—Pumped Hydro; CA—Compressed Air; F-Flywheels; SC—Super-Capacitors; RfB—Redox flow Batteries; LB—Lithium Batteries; $\mathrm{H}-$ Hydrogen storage.

Finally, with the information reviewed on the websites of the projects that passed the third filter of the first phase, and the information gathered from the interviews carried out after the online survey, we can affirm that there are no specific reports or activities in any of the projects that demonstrate a concern for the aesthetic impact of the facilities, nor an express desire to evaluate the aesthetic perception of the facilities by society.

\subsection{Entities Involved}

The composition of the consortium of these projects was varied and normally included public entities, research institutions, non-governmental organizations (NGOs), agencies, companies, and others. The profile of the partners for the 16 projects analyzed in detail in our study is shown in Figure 2. and most of them were private companies. The presence of public entities, universities or research institutions, and agencies/platforms/NGOs was similar.

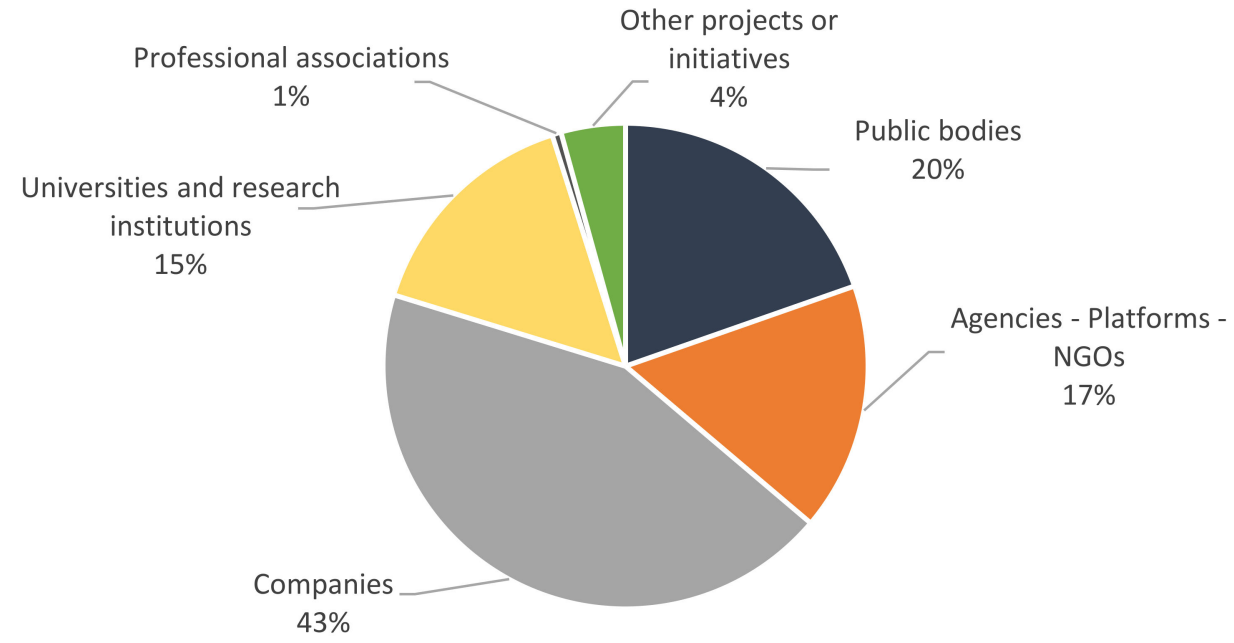

Figure 2. Profile of the partners in the European projects surveyed.

The fact of working with data on the built environment (e.g., consumption, volumetry, density, energy management, etc.), besides the necessary capacity to influence local policies for a real implementation of RE, makes the participation of public entities essential for this kind of projects. After analyzing the set of 16 URIPs, public administrations were found to be partners in all cases and coordinating partners in four cases $(25 \%)$. This latter result could likely be explained by the very complexity of their bureaucratic functioning, which 
is also the reason it was exceedingly difficult to get information when required throughout the survey.

It should be noted that the public institutions involved in these projects were always at the local level, which makes it difficult to intervene in policies at the state level that might have a multiplier effect for this type of urban intervention as part of the necessary energy transition.

As shown in Figure 3, the most common partners were the groups formed by private companies, agencies, NGOs, platforms, and others. They represented more than $50 \%$ of projects except for CityKeys (11\%), ZenN (25\%), and HeatNET NWE (38\%) projects, for which municipalities had a greater presence. However, public entities, referring to cities or municipalities, were between 15 and $25 \%$ of the consortium and were a lower percentage for City-zen (11\%) and a higher percentage for HeatNET NWE (38\%) and ZenN (42\%) and extraordinarily large for CityKeys at $56 \%$.

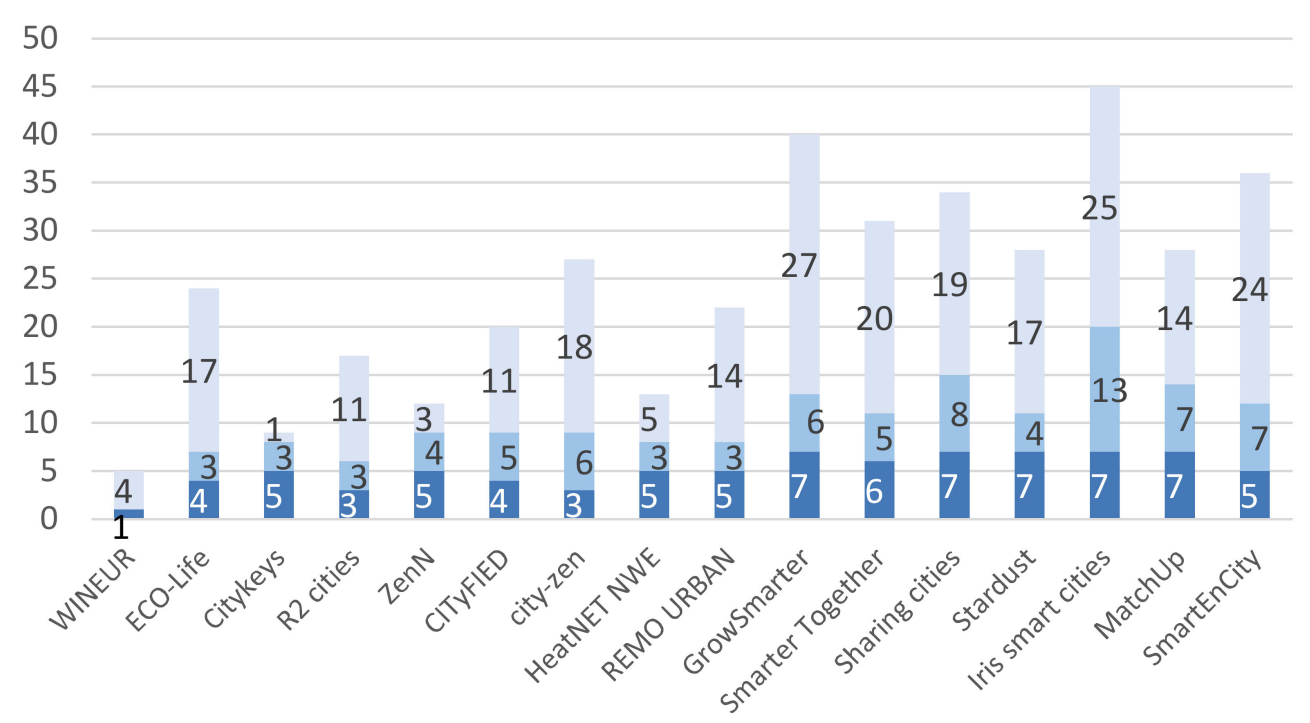

Figure 3. Types of partners in the 16 projects examined.

\section{Discussion}

\subsection{Renewable Energy Integration in the City}

According to the revision made, our first conclusion is that even though Europeanfunded projects have a clear interest in RES and SES, it is still from a theoretical point of view, seeking awareness, dissemination, and cooperation. Therefore, to provide data from actual demonstrations with efficient solutions applicable to other territories seems to be extremely complicated. According to the survey results shown in Table 4, the most used renewable energy systems on an urban scale are, in this sequence: photovoltaic (all projects except SmartEnCity), thermal solar (ECO-Life, Remourban, and Smarter Together 1), geothermal (ECO-Life, Remourban, and Smarter Together 2) and biomass systems (Smarter Together 1 and SmartEnCity). Regarding energy storage, lithium batteries are commonly associated with solar energy systems and seem to be the most widespread solution (in Remourban, GrowSmarter, and Smarter Together 2). Overall, as shown in Table 3, the number of European-funded projects that meet the requirements of the study was low and the number that considered integrated SES was even lower. Nevertheless, an increase in research to optimize this situation is still foreseeable, since according to prior literature, this type of project is of vital importance for more sustainable development [26,29-31]. Additionally, an increase of this type of project could favor the awareness, the standardization, and the improvement of the aesthetic acceptance by society.

In the literature review, a great interest in research that includes SES into urban energy systems was observed $[26,28,33-36]$. And several authors highlighted the benefits of a 
higher storage capacity $[37,73]$. Unfortunately, the survey findings demonstrated that real implementation of SES at an urban scale in European-funded projects is still scarce.

In the field of thermal energy, the scope of the examined projects seems greater, but they have not been finally included in our study unless they were combined with other renewable energy systems because they are usually buried and do not have a significant visual impact.

\subsection{Temporal and Policy Frame}

Based on the current review of EU-funded projects, Figure 4 shows the evolution over time, since 2000, for the 63 projects that passed the second filter because of their relationship with the implementation of RES in the city. For each project, all the years of the program were marked. Three stages were clearly distinguishable with similarities to other studies in the literature in public expenditures on research and development for the renewable energy transition in Europe and are shown in this figure [74].

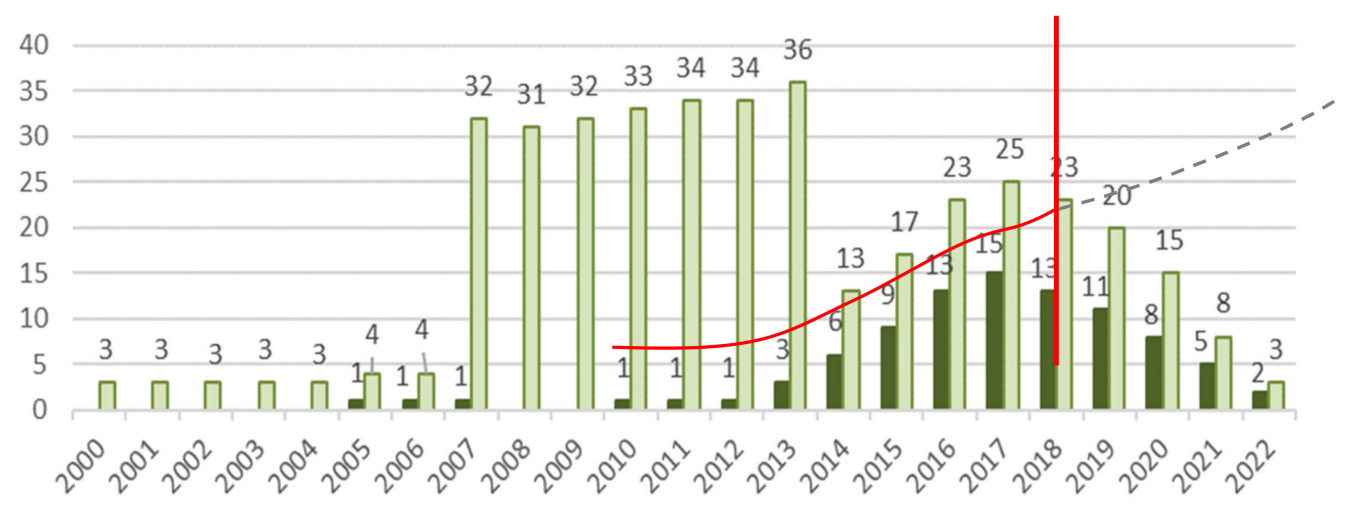

Filter 3 afilter 2

Figure 4. Number of projects per year applying filters 2 and 3.

Funding for new alternative energy sources to fossil fuels started in the early seventies during the Arab-Israeli War. At the end of the nineties, there was a new impulse for renewable energies [74]. Throughout these first years, the efforts were implemented in rural environments in the form of wind farms, photovoltaic plants, or biomass plants, among others. A register of funded projects, that in the title showed an intention to implement renewable energies on an urban scale (passing the second filtering step), started in 2000. The first stage clearly comprises the 5-year time period (2000-2006) as shown in Figure 4. This stage is characterized by a small number of projects ( 3 or 4 ) that yearly passed the second filtering step, and by one project that passed the third filtering step (i.e., real implementation of RES on an urban scale).

The second stage comprises the years 2007-2013, which coincides with the economic crisis. As seen in Figure 4, the year 2007 marked a turning point for the European Union's climate and energy policy [75] resulting in the Directive 2009/28/EC, with the agreement to set targets on greenhouse gas emissions (a reduction of at least $20 \%$ by 2020 from the 1990 baseline), energy efficiency (savings of $20 \%$ by 2020, expressed absolutely), and uptake of renewable energy (achievement of a $20 \%$ share of renewable energy in EU energy consumption by 2020). In the same year, the Strategic Energy Technology (SET) Plan [76] was also published by the European Commission, which aimed to coordinate EU, national, and private funding efforts in technology research and development to accelerate the EU's transformation to a low-carbon energy system [77]. In this stage, a significant number of projects in the Interreg Program passed the criteria established in the second filtering step, but most of them were posteriorly discarded through the third filtering step as these projects were exclusively framed as policy interventions and not 
from a practical or empirical perspective [78] or because they affected individual buildings without urban integration.

Finally, continuous growth of potential projects with actions related to the real implementation of RES in urban environments (passing the third filtering step in our study) is shown in the third stage, from 2013 onwards. These projects were funded by the FP7 and H2020 programs. In 2014, the European Commission proposed ambitious energy efficiency targets by 2030 [79], such as a $40 \%$ reduction in greenhouse gas emissions from the 1990 baseline or a $27 \%$ share of renewable energy consumption. At the end of 2016, a package of measures to position the European Union to lead the clean energy transition was presented by the European Commission [80], resulting in the Clean Energy for All Europeans package [4]. One of the main goals was to put consumers at the heart of the Energy Union.

As the current revision was conducted at the end of 2018, all projects financed in the European calls from the same year onwards have not been considered, which explains why the trend in increased projects in the last period peaked in 2017. Accordingly, including the projects selected in subsequent calls, it would be expected that the above trend will continue.

From a political perspective, we found authors stating that, although in Europe there is a growing trend of projects to implement renewable energy, the investment of Member States is higher than that made by the European Commission [74]. From a holistic point of view, the integration of energy systems must be a bespoke approach that considers the characteristics and needs of the system. In order to reduce risks and prevent duplication of effort, greater coordination at the European level would be desirable by looking at successful pilot projects and ensuring access to the final results [81].

On the other hand, the literature review showed a constant development of the European policy frame related to the use of energy from renewable sources, the greenhouse gas emissions, the energy efficiency, or the very elements that make up solar energy installations in buildings. However, there is no specific guideline at the European level that regulates or promotes the aesthetic integration of these systems.

\subsection{Geographical Frame}

The information collected from the websites of the 16 projects selected after applying the third filter allowed us to analyze the geographical frame of the real integration of renewable energies on an urban scale. As shown in Figure 5, Spain is the country that stands out most for its participation and its role as coordinator in the examined funded projects. Indeed, Belgium and Spain are the countries that have participated in the largest number of projects $(69 \%)$, followed by Italy $(56 \%)$ and Germany $(50 \%)$. This result certainly contrasts with the statistics corresponding to the number of countries coordinating these projects. Thus, although $44 \%$ of the projects were coordinated by Spain, only one project was coordinated by Belgium and none by Italy or Germany. In both northern and eastern Europe, participation has been quite low, and many countries in eastern Europe have not participated in any of the revised projects.

It is interesting to note that, during this validation process, the reasons for working on this type of research project are very different in non-European countries and less developed environments (e.g., the lack of electricity supply in some underdeveloped areas). Additionally, for some countries with later and lesser implementation of solar energy (such as Spain), the focus of the scientific work has been on improving efficiency but reducing cost. However, other relevant issues, such as social acceptance, solidarity between neighbors (i.e., quantifying and sharing energy), and aesthetic perception, have not been considered priorities. 


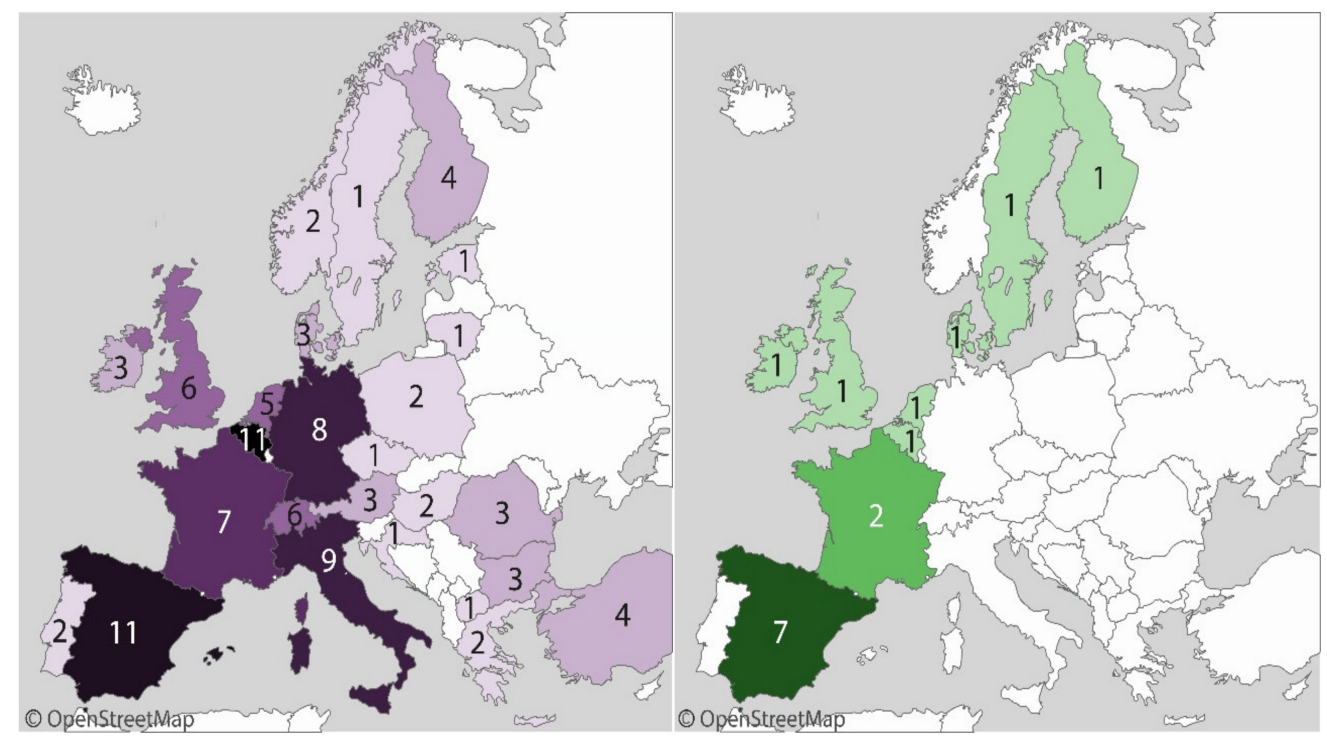

Figure 5. Geographical frame for the 16 European projects identified that include real implementation of RES on an urban scale. Left: Number in which the country is involved. Right: Number in which the country is coordinator. The color gets darker as the number gets higher.

\subsection{Citizen Involvement in the Energy Transition}

Implementation and integration of renewable energies at the urban level undoubtedly effects citizens, especially residents and people who work or circulate in the affected areas. However, in the analyzed projects, there were no local neighborhood associations or entities that would represent them, meaning that citizens were represented by the municipality itself, by agencies, or by NGOs, with the exception of the SmartEnCity project in which the B42 Housing Association was a partner in the consortium. Therefore, the three dimensions of social acceptance (sociopolitical, communitarian, and market) [44], are generally not well-represented. This finding coincides with the conclusions of a previous study that stated that few of these kinds of studies implementing RES and ESS included more than one of these three aspects in their analytical frameworks [40]. Additionally, to promote social acceptance, the participation and involvement of residents is necessary [19,45-47]. Consequently, the social sector should be included in the consortia of these Europeanfunded projects to improve social acceptance outcomes. It should not be forgotten that energy transition requires a change in consciousness, habits, and behaviors in society for these initiatives to be truly effective, which further justifies the involvement of citizens in the projects [49].

Notwithstanding, the inclusion of the social sector in this organizational cooperation seems to be indispensable. In this sense, we totally agree with the statement of a prior study regarding that "policy discussions should openly consider the role of perceptions of citizens in order to articulate sustainable and acceptable solutions" [82].

In this regard, the response regarding citizen participation according to the interviews conducted in this study was particularly curious. While activities that would allow residents to participate in the project were positively planned in the milestones, these important outcomes were not reflected in the information posted on the web page of the corresponding projects, which could be a relevant finding of the current review.

\subsection{Aesthetics in the H2020 Program}

Currently, science policy incorporates public policy goals in an attempt to increase the transfer of scientific contributions to society as plausible solutions to relevant societal problems. Scientists have responded to this new funding strategy by casting their fields and topics as particularly promising. There can be little doubt that in addition to the window dressing triggered by targeted funding, such funding also has increased research 
on the intended topics [83]. A deeper analysis of the interrelations between science policy and public policy goals was performed throughout the energy-related funding calls of the Horizon 2020 Program. Indeed, a large number of projects that passed the third filtering step in our study were included in this program.

Horizon 2020 focuses on three main pillars: (a) excellent science to strengthen the Union's world-class scientific excellence and make Union research and innovation systems more competitive, (b) fostering industrial leadership to speed the development of technologies that will support businesses and innovation, including for small companies, and (c) tackling societal challenges to respond to the priorities identified in the Europe 2020 strategy. In this line, energy is giving explicit attention under the societal challenge 10 'Secure, Clean and Efficient Energy'. Calls in this challenge have a total budget for non-nuclear research of almost $€ 6$ billion over 2014-2020. Each new biannual work package (2014-2015 WP, 2016-2017 WP, and 2018-2020 WP) adopts the reinforcements and updates of the SET Plan [76].

The keywords 'aesthetics' and 'visual' were included in the search conducted for the three work packages in the challenge. For the two last WPs [80,84], the keyword 'visual' was related to visual comfort, considered a characteristic of indoor environmental quality, as is thermal comfort, acoustics, or air quality. However, no results were found in the first WP [85]. During the last WP, transparent, 'visually nonintrusive' photovoltaic windows were expected technologies (although from TRL 3 to at least 5) in the LC-SC3-RES-2-2018 'Disruptive innovation in clean energy technologies' call [84].

During the 2014-2015 WP, the word 'aesthetic' appeared in one call about renewable energies (LCE 3 - 2014/2015) that was related to photovoltaics integrated into the built environment, such as architectural considerations. During the next WP, the word 'aesthetic' appeared in one call, whereas aesthetics was one of the criteria of the 'Horizon prize for Integrated Photovoltaic System in European Protected Historic Urban districts'. In the 2018-2020 WP, the word 'aesthetic' appeared in one call related to BIPV (LC-SC3-RES6-2018) and as novelty in one call (LC-SC3-EC-1-2018-2019-2020) to develop activities informing and motivating consumers to change old and inefficiently installed appliances to more efficient and clean energy heating and/or cooling solutions.

Changes in the SET Plan due to the 'Clean Energy for all Europeans' package measures [80] reoriented the 2016-2017 Energy WP compared with its 2014-2015 predecessor with particular emphasis on enabling consumers to actively participate in the energy transition. The consequences of the aesthetic impact of renewable energies include consideration of visual comfort and awareness activities in changing the market.

These WPs align with a dominant understanding of consumers as rational individuals whose decisions and behaviors are determined by preset beliefs and attitudes. Within this paradigm, pro-environmental behavior-change focuses on decision-making and choice, and therefore, is often targeted through providing information and increasing awareness [86].

Consequently, forthcoming funding calls should consider technologies as products and core constituents of work and everyday life and not only as a means of intervention. It is indeed essential that technological change is not separated from social change [86]. In this regard, technological change should not be separated from social change but rather the energy transition should rely on educating citizens as end-users of the product. To achieve effective and efficient energy savings, it seems extremely important to change consumption habits in the first place by making the population aware of the fact that they are real users who must accept the challenge of renewable energies for their own sake and that of future generations. To this extent, considering the opinions of citizens on the aesthetic impact of these technologies over the skyline could certainly prevent rejection by future users. Consequently, from our standpoint, the energy transition challenge might be seen as a phenomenon of human-environment interaction, and therefore, the research focus should change to facilitate the transfer of knowledge to the real world through the involvement of cities and their citizens. 


\subsection{Limitations}

The revision of European URIPs conducted in our study is innovative, groundbreaking, and pioneering in the field of energy-related European programs. However, our research was limited to 5 specific and well-known funding programs in this area, and there could exist other initiatives or funding resources that have not been considered in our study. Although other regions such as the USA, China, Japan, or South Korea have a potential interest in the field of renewable energy integration, this research was focused narrowly on Europe and included almost 14,000 projects. A broader analysis, contrasting results with other regions of interest, could certainly be the focus of further research.

The projects were previously filtered from several European Commission funding programs. European member states have their own $\mathrm{R}+\mathrm{D}$ expenditures programs. Other studies have found that the budget for renewable energy from European member states is about six times higher than those of the EC, but the trends over time are quite similar [75]. For example, in a country such as Germany that has not stood out for coordinating such projects (see Figure 5), the Environment Ministry manages several projects of seasonal storage, and technologies have been continuously researched and developed since 1993 (www.saisonalspeicher.de). Additionally, the Federal Ministry of Education and Research and the Federal Ministry of Economics and Energy allocate many resources to research and implementation projects promoting energy efficiency and energy transition (e.g., FutureSuN project, QUARREE 100 project).

The projects were consecutively filtered based on previously established keywords or topics according to their title and summary or consulting their web pages (i.e., first, second, and third filtering steps, respectively). It is possible that some projects did not pass any of the filters despite its consideration of the aesthetic impact. However, the answers to the questionnaire led us to the same conclusion about the scarcity concern that has existed, until now, on this subject. Moreover, the web pages of the funded projects consulted during the search were, in many cases, truly short or vague, especially for old projects. Consequently, sometimes it was difficult to apply the third filtering step. Furthermore, information about citizen participation, aesthetic impact, and photographs of the implementation were rarely found on these web pages.

Another limitation was the low quality of the electronic survey responses collected in the second phase of our study. It should be highlighted that many projects were still ongoing (not finished) at the time of this survey.

The scope of the current research was projects aimed at the deployment of renewable energies in cities. In this regard, solar technologies are the most funded facilities compared to other technologies such as geothermal and biomass with practically no aesthetic impact since they are buried or hidden inside the buildings.

Lastly, it should be noted that this study in no way evaluates the aesthetic impact of the European projects analyzed, nor the social perception of these projects.

\section{Conclusions}

The main purpose of this work was to identify European-funded projects with a real implementation of renewable energies in cities, called URIPs, and to analyze their concern for the aesthetic impact they produce. To this aim, a systematic search of European projects was conducted including almost 14,000 projects from the 5 programs considered most relevant to the promotion of renewable energies and climate change mitigation.

The current study shows that although European-funded projects have a strong relationship with the development and promotion of renewable energies, their involvement in real implementation of these technologies on an urban scale is still low. Since 2013, however, research has grown for potential projects with actions related to the actual implementation of RES in urban environments.

Among projects identified with actual deployment of renewable energies in cities, the most implemented RES was clearly photovoltaic technology and, in some cases, solar 
thermal, biomass, and/or geothermal projects. On the other hand, the use of energy storage systems was not so widespread, with lithium batteries as the most commonly used type.

Since 2000, the evolution over time reflects three distinguished stages. The first stage, covering from 2000 to 2006, would be characterized by a small number of projects. The second stage, which comprises from 2007 to 2013, could be outlined with a significant number of projects thanks to the encouragement of European policies, although most of them were exclusively framed as policy interventions and not from a practical or empirical perspective. In the last stage, from 2013 onwards, a continuous growth of potential projects was observed.

In addition, the analysis of geographical frames for participation in these kinds of projects showed unequal involvement among European countries. While there has been greater participation of entities from Spain, Belgium, Italy, Germany, and France, other countries from the north and east of Europe have lower participation.

Furthermore, most of the European-funded projects included in this study were financed by the H2020 program. A deeper analysis of this program revealed that the aesthetic impact of the proposed technologies for the promotion of renewable energies has never been considered a key topic. However, since 2014 the word 'aesthetic' has begun to appear as a specific call of each biannual work package related to architectural integration of photovoltaics.

The study carried out allows us to affirm that European URIPs do not currently show any particular concern for the aesthetic impact they cause in the city, nor for the evaluation of the aesthetic perception of the affected society.

From a policy perspective, encouraging more coordinated work of research centers, industrial sector, technicians and public administrations would favor a better integration and a greater social acceptance of renewable energies in the urban environment.

Finally, we would like to highlight that forthcoming funding calls should start to consider the technologies as products and core constituents of work and everyday life and not only as a means of intervention to promote energies that are cleaner, renewable, and thus help us preserve the planet. If we want to promote a real implementation of renewable energies in our cities, we must consider these facilities as a product that will be naturally present in our daily life, and that society must know and standardize.

Supplementary Materials: The survey is available online at https:/ /www.mdpi.com/1996-1073/14 /6/1627/s1. Short survey designed including specific questions about the project and the facilities features implemented.

Author Contributions: Conceptualization, N.S.-P. and R.V.; methodology, N.S.-P. and R.V.; investigation, N.S.-P.; writing - original draft preparation, N.S-P., and R.V.; writing-review and editing, N.S.-P., R.V. and M.C.P.; visualization, N.S.-P.; supervision, R.V. and M.C.P. All authors have read and agreed to the published version of the manuscript.

Funding: Partial funding: Project STABLE PID2019-107314RB-I00.

Institutional Review Board Statement: Not applicable.

Informed Consent Statement: Not applicable.

Data Availability Statement: The data presented in this study are available in article and supplementary material.

Acknowledgments: The authors acknowledge financial support from Ministry of Science and Innovation of Spain under Project STABLE PID2019-107314RB-I00. The authors would like to thank the group pf experts from the Energy Engineering Institute of the Polytechnic University of Valencia who helped us to validate the questions included in the survey designed for collecting additional information in phase two of our study.

Conflicts of Interest: The authors declare no conflict of interest. 


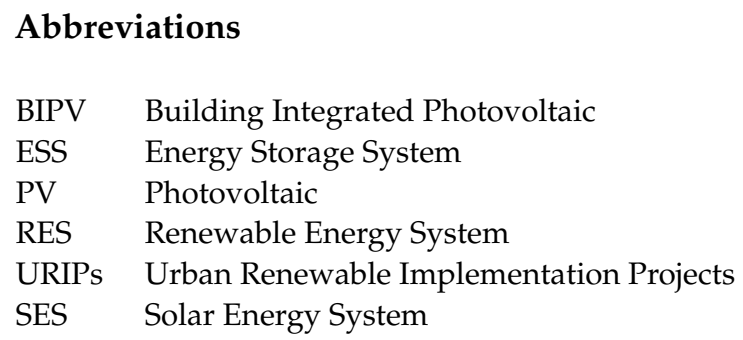

\section{References}

1. EU EUROPE. A Strategy for Smart, Sustainable and Inclusive Growth; EU EUROPE: Brussels, Belgium, 2010.

2. EU. Directiva 2002/91/CE; EU: Brussels, Belgium, 2003; Volume 1, pp. 65-71.

3. EU. Establishing Horizon 2020-The Framework Programme for Research and Innovation (2014-2020); EU: Brussels, Belgium, 2014.

4. European Commission. Clean Energy for All Europeans; European Commission: Brussels, Belgium, 2019.

5. Sánchez-Pantoja, N.; Vidal, R.; Pastor, M.C. Aesthetic perception of photovoltaic integration within new proposals for ecological architecture. Sustain. Cities Soc. 2018, 39, 203-214. [CrossRef]

6. D'Orazio, M.; Di Perna, C.; Di Giuseppe, E. Performance assessment of different roof integrated photovoltaic modules under Mediterranean Climate. Energy Procedia 2013, 42, 183-192. [CrossRef]

7. Loulas, N.M.; Karteris, M.M.; Pilavachi, P.A.; Papadopoulos, A.M. Photovoltaics in urban environment: A case study for typical apartment buildings in Greece. Renew. Energy 2012, 48, 453-463. [CrossRef]

8. Makrides, G.; Zinsser, B.; Norton, M.; Georghiou, G.E.; Schubert, M.; Werner, J.H. Potential of photovoltaic systems in countries with high solar irradiation. Renew. Sustain. Energy Rev. 2010, 14, 754-762. [CrossRef]

9. Makrides, G.; Zinsser, B.; Phinikarides, A.; Schubert, M.; Georghiou, G.E. Temperature and thermal annealing effects on different photovoltaic technologies. Renew. Energy 2012, 43, 407-417. [CrossRef]

10. Makrides, G.; Zinsser, B.; Schubert, M.; Georghiou, G.E. Seasonal performance comparison of different photovoltaic technologies installed in Cyprus and Germany. Int. J. Sustain. Energy 2013, 32, 466-488. [CrossRef]

11. Bonomo, P.; Frontini, F.; De Berardinis, P.; Donsante, I. BIPV: Building envelope solutions in a multi-criteria approach. A method for assessing life-cycle costs in the early design phase. Adv. Build. Energy Res. 2017, 11, 104-129. [CrossRef]

12. Hemmerle, C.; Hemmerle, C. Solar PV building skins: Structural requirements and environmental benefits. J. Facade Des. Eng. 2016, 5, 93-105. [CrossRef]

13. Sagani, A.; Mihelis, J.; Dedoussis, V. Techno-economic analysis and life-cycle environmental impacts of small-scale buildingintegrated PV systems in Greece. Energy Build. 2017, 139, 277-290. [CrossRef]

14. Yang, R.J.; Zou, P.X.W. Building integrated photovoltaics (BIPV): Costs, benefits, risks, barriers and improvement strategy. Int. J. Constr. Manag. 2016, 16, 39-53. [CrossRef]

15. Lu, M.; Lin, A.; Sun, J. The impact of photovoltaic applications on urban landscapes based on visual Q methodology. Sustainability 2018, 10, 1051. [CrossRef]

16. Naspetti, S.; Mandolesi, S.; Zanoli, R. Using visual Q sorting to determine the impact of photovoltaic applications on the landscape. Land Use Policy 2016, 57, 564-573. [CrossRef]

17. Xu, R.; Wittkopf, S.; Roeske, C. Quantitative evaluation of BIPV visual impact in building retrofits using saliency models. Energies 2017, 10, 668. [CrossRef]

18. Zhai, P.; Williams, E. Analyzing consumer acceptance of photovoltaics (PV) using fuzzy logic model. Renew. Energy 2012, 41, 350-357. [CrossRef]

19. Strazzera, E.; Statzu, V. Fostering photovoltaic technologies in Mediterranean cities: Consumers' demand and social acceptance. Renew. Energy 2017, 102, 361-371. [CrossRef]

20. Chen, H.Q.; Honda, T.; Yang, M.C. Approaches for identifying consumer preferences for the design of technology products: A case study of residential solar panels. J. Mech. Des. 2013, 135, 061007. [CrossRef]

21. Bao, Q.; Honda, T.; El Ferik, S.; Shaukat, M.M.; Yang, M.C. Understanding the role of visual appeal in consumer preference for residential solar panels. Renew. Energy 2017, 113, 1569-1579. [CrossRef]

22. Hille, S.L.; Curtius, H.C.; Wüstenhagen, R. Red is the new blue-The role of color, building integration and country-of-origin in homeowners' preferences for residential photovoltaics. Energy Build. 2018, 162, 21-31. [CrossRef]

23. Lucchi, E.; Polo Lopez, C.S.; Franco, G. A conceptual framework on the integration of solar energy systems in heritage sites and buildings. IOP Conf. Ser. Mater. Sci. Eng. 2020, 949, 012113. [CrossRef]

24. Pelle, M.; Lucchi, E.; Maturi, L.; Astigarraga, A.; Causone, F. Coloured BIPV technologies: Methodological and experimental assessment for architecturally sensitive areas. Energies 2020, 13, 4506. [CrossRef]

25. Akinyele, D.O.; Rayudu, R.K. Review of energy storage technologies for sustainable power networks. Sustain. Energy Technol. Assessments 2014, 8, 74-91. [CrossRef]

26. Luo, X.; Wang, J.; Dooner, M.; Clarke, J. Overview of current development in electrical energy storage technologies and the application potential in power system operation. Appl. Energy 2015, 137, 511-536. [CrossRef] 
27. Gößling-Reisemann, S.; Wachsmuth, J.; Stührmann, S.; von Gleich, A. Climate change and structural vulnerability of a metropolitan energy system: The case of Bremen-Oldenburg in Northwest Germany. J. Ind. Ecol. 2013, 17, 846-858. [CrossRef]

28. IRENA. Electricity Storage and Renewables: Costs and Markets to 2030; IRENA: Abu Dhabi, UAE, 2017 ; ISBN 9789292600389.

29. Perea-Moreno, M.-A.; Hernandez-Escobedo, Q.; Perea-Moreno, A.-J. Renewable energy in urban areas: Worldwide research trends. Energies 2018, 11, 577. [CrossRef]

30. Amado, M.; Poggi, F.; Amado, A.R. Energy efficient city: A model for urban planning. Sustain. Cities Soc. 2016, 26, 476-485. [CrossRef]

31. Curreli, A.; Serra-Coch, G.; Isalgue, A.; Crespo, I.; Coch, H. Solar energy as a form giver for future cities. Energies 2016, 9 , 544. [CrossRef]

32. Rae, C.; Bradley, F. Energy autonomy in sustainable communities-A review of key issues. Renew. Sustain. Energy Rev. 2012, 16, 6497-6506. [CrossRef]

33. Navarro, L.; de Gracia, A.; Niall, D.; Castell, A.; Browne, M.; McCormack, S.J.; Griffiths, P.; Cabeza, L.F. Thermal energy storage in building integrated thermal systems: A review. Part 2. Integration as passive system. Renew. Energy 2016, 85, 1334-1356. [CrossRef]

34. Navarro, L.; de Gracia, A.; Colclough, S.; Browne, M.; McCormack, S.J.; Griffiths, P.; Cabeza, L.F. Thermal energy storage in building integrated thermal systems: A review. Part 1. active storage systems. Renew. Energy 2016, 88, 526-547. [CrossRef]

35. Amirante, R.; Cassone, E.; Distaso, E.; Tamburrano, P. Overview on recent developments in energy storage: Mechanical, electrochemical and hydrogen technologies. Energy Convers. Manag. 2017, 132, 372-387. [CrossRef]

36. Cebulla, F.; Haas, J.; Eichman, J.; Nowak, W.; Mancarella, P. How much electrical energy storage do we need? A synthesis for the U.S., Europe, and Germany. J. Clean. Prod. 2018, 181, 449-459. [CrossRef]

37. Freitas, S.; Reinhart, C.; Brito, M.C. NO-Minimizing storage needs for large scale photovoltaics in the urban environment. Sol. Energy 2018, 159, 375-389. [CrossRef]

38. Vlad, A.; Singh, N.; Galande, C.; Ajayan, P.M. Design considerations for unconventional electrochemical energy storage architectures. Adv. Energy Mater. 2015, 5, 1402115. [CrossRef]

39. Curtius, H.C. The adoption of building-integrated photovoltaics: Barriers and facilitators. Renew. Energy 2018, 126, 783-790. [CrossRef]

40. Devine-Wright, P.; Batel, S.; Aas, O.; Sovacool, B.; Labelle, M.C.; Ruud, A. A conceptual framework for understanding the social acceptance of energy infrastructure: Insights from energy storage. Energy Policy 2017, 107, 27-31. [CrossRef]

41. Sánchez-Pantoja, N.; Vidal, R.; Pastor, M.C. Aesthetic impact of solar energy systems. Renew. Sustain. Energy Rev. 2018, 98, 227-238. [CrossRef]

42. Werner, S. International review of district heating and cooling. Energy 2017, 137, 617-631. [CrossRef]

43. Reinhart, C.F.; Cerezo, C. Urban building energy modeling-A review of a nascent field. Build. Environ. 2016, 97, 196-202. [CrossRef]

44. Wüstenhagen, R.; Wolsink, M.; Bürer, M.J. Social acceptance of renewable energy innovation: An introduction to the concept. Energy Policy 2007, 35, 2683-2691. [CrossRef]

45. Flacke, J.; de Boer, C. An interactive planning support tool for addressing social acceptance of renewable energy projects in The Netherlands. ISPRS Int. J. Geo-Inf. 2017, 6, 313. [CrossRef]

46. Langer, K.; Decker, T.; Menrad, K. Public participation in wind energy projects located in Germany: Which form of participation is the key to acceptance? Renew. Energy 2017, 112, 63-73. [CrossRef]

47. Zoellner, J.; Schweizer-Ries, P.; Wemheuer, C. Public acceptance of renewable energies: Results from case studies in Germany. Energy Policy 2008, 36, 4136-4141. [CrossRef]

48. Wachsmuth, J. Cross-sectoral integration in regional adaptation to climate change via participatory scenario development. Clim. Chang. 2015, 132, 387-400. [CrossRef]

49. Grimm, V.; Kretschmer, S.; Mehl, S. Green innovations: The organizational setup of pilot projects and its influence on consumer perceptions. Energy Policy 2020, 142, 1-14. [CrossRef]

50. Faiers, A.; Neame, C. Consumer attitudes towards domestic solar power systems. Energy Policy 2006, 34, 1797-1806. [CrossRef]

51. Aas, Ø.; Devine-Wright, P.; Tangeland, T.; Batel, S.; Ruud, A. Public beliefs about high-voltage powerlines in Norway, Sweden and the United Kingdom: A comparative survey. Energy Res. Soc. Sci. 2014, 2, 30-37. [CrossRef]

52. Basecq, V.; Michaux, G.; Inard, C.; Blondeau, P. Short-term storage systems of thermal energy for buildings: A review. Adv. Build. Energy Res. 2013, 7, 66-119. [CrossRef]

53. Ürge-Vorsatz, D.; Cabeza, L.F.; Serrano, S.; Barreneche, C.; Petrichenko, K. Heating and cooling energy trends and drivers in buildings. Renew. Sustain. Energy Rev. 2015, 41, 85-98. [CrossRef]

54. Rempel, A.R.; Rempel, A.W. Rocks, clays, water, and salts: Highly durable, infinitely rechargeable, eminently controllable thermal batteries for buildings. Geosciences 2013, 3, 63-101. [CrossRef]

55. Ruth, M.; Özgün, O.; Wachsmuth, J.; Gößling-Reisemann, S. Dynamics of energy transitions under changing socioeconomic, technological and climate conditions in Northwest Germany. Ecol. Econ. 2015, 111, 29-47. [CrossRef]

56. Von Gleich, A.; Gößling-Reisemann, S.; Stührmann, S.; Woizeschke, P.; Lutz-Kunisch, B. Resilienz als Leitkonzept-vulnerabilität als analytische Kategorie. Theor. Grundl. Erfolgreiche Klimaanpassungsstrategien. Bremen. Proj. Nord. 2010, 1, 13-49. 
57. Torres-Sibille, A.C.; Cloquell-Ballester, V.-A.; Cloquell-Ballester, V.-A.; Artacho, M.A. Aesthetic impact assessment of solar power plants: An objective and a subjective approach. Renew. Sustain. Energy Rev. 2009, 13, 986-999. [CrossRef]

58. Scognamiglio, A. "Photovoltaic landscapes": Design and assessment. A critical review for a new transdisciplinary design vision. Renew. Sustain. Energy Rev. 2016, 55, 629-661. [CrossRef]

59. Chiabrando, R.; Fabrizio, E.; Garnero, G. On the applicability of the visual impact assessment OAISPP tool to photovoltaic plants Renew. Sustain. Energy Rev. 2011, 15, 845-850. [CrossRef]

60. Kapetanakis, I.A.; Kolokotsa, D.; Maria, E.A. Parametric analysis and assessment of the photovoltaics' landscape integration: Technical and legal aspects. Renew. Energy 2014, 67, 207-214. [CrossRef]

61. Mérida-Rodríguez, M.; Lobón-Martín, R.; Perles-Roselló, M. The production of solar photovoltaic power and its landscape dimension. In Renewable Energies and European Landscapes; Springer: Dordrecht, The Netherlands, 2015; pp. 255-277, ISBN 978-94017-9843-3.

62. Tolli, M.; Recanatesi, F.; Piccinno, M.; Leone, A. The assessment of aesthetic and perceptual aspects within environmental impact assessment of renewable energy projects in Italy. Environ. Impact Assess. Rev. 2016, 57, 10-17. [CrossRef]

63. Von Möllendorff, C.; Welsch, H. Measuring renewable energy externalities: Evidence from subjective well-being data. Land Econ. 2017, 93, 109-126. [CrossRef]

64. Florio, P.; Munari, M.C.; Schüler, A.; Roecker, C.; Scartezzini, J.L. Assessing visibility in multi-scale urban planning: A contribution to a method enhancing social acceptability of solar energy in cities. Sol. Energy 2018, 173, 97-109. [CrossRef]

65. Klæboe, R.; Sundfør, H.B. Windmill noise annoyance, visual aesthetics, and attitudes towards renewable energy sources. Int. J. Environ. Res. Public Health 2016, 13, 746. [CrossRef]

66. Butler, A.; Wärnbäck, A. Landscape and Wind Energy; Swedish University of Agricultural Sciences: Uppsala, Sweden, 2019; Volume 4, ISBN 9789185735587.

67. EU. Directive 2009/28/EC; EU: Brussels, Belgium, 2009; Volume 1, pp. 32-38.

68. Lacal, R.; Jäger-Waldau, A. Photovoltaics and wind status in the European Union after the Paris Agreement. Renew. Sustain. Energy Rev. 2018, 81, 2460-2471. [CrossRef]

69. Winkler, J.; Ragawitz, M. Solar Energy Policy in the EU and the Member States, from the Perspective of the Petitions Received; European Comission: Brussels, Belgium, 2016; Volume 44.

70. United Nations. Paris Agreement; United Nations: New York, NY, USA, 2015.

71. United Nations. Paris Agreemen, Entry into Force; United Nations: New York, NY, USA, 2016; p. 1.

72. Macé, P.; Neuborg, G.; Serra, G.; Detollenaere, A.; Frontini, F. BIPVBOOST D9.2 Regulatory Framework for BIPV; European Commission: Brussels, Belgium, 2019.

73. Lovati, M.; Salvalai, G.; Fratus, G.; Maturi, L.; Albatici, R.; Moser, D. New method for the early design of BIPV with electric storage: A case study in northern Italy. Sustain. Cities Soc. 2018, 48, 101400. [CrossRef]

74. Bointner, R.; Pezzutto, S.; Grilli, G.; Sparber, W. Financing innovations for the renewable energy transition in Europe. Energies 2016, 9, 990. [CrossRef]

75. EU. 2020 by 2020 Europe's Climate Change Opportunity; EU: Brussels, Belgium, 2008.

76. EU. A European Strategic Energy Technology Plan (SET-Plan)_“Towards a Low Carbon Future”; OPOCE: Brussels, Belgium, 2007.

77. Moseley, P. EU support for innovation and market uptake in smart buildings under the Horizon 2020 framework programme. Buildings 2017, 7, 105. [CrossRef]

78. Spurling, N.; Mcmeekin, A.; Shove, E.; Southerton, D.; Welch, D. Interventions in Practice: Re-Framing Policy Approaches to Consumer Behaviour; Lancaster University: Lancaster, LA, USA, 2013.

79. EU. A Policy Framework for Climate and Energy in the Period from 2020 to 2030; OPOCE: Brussels, Belgium, 2014.

80. EU. Clean Energy For All Europeans; EU: Brussels, Belgium, 2016.

81. Cambini, C.; Congiu, R.; Jamasb, T.; Llorca, M.; Soroush, G. Energy Systems Integration: Implications for Public Policy. Energy Policy 2020, 2020, 111609. [CrossRef]

82. Loureiro, M.L.; Alló, M. Sensing climate change and energy issues: Sentiment and emotion analysis with social media in the U.K. and Spain. Energy Policy 2020, 143, 111490. [CrossRef]

83. Gläser, J.; Laudel, G. Governing science. How science policy shapes research content abstract. Eur. J. Sociol. 2016, 57, 117-168. [CrossRef]

84. EU. Horizon 2020 Challenge 10. Secure, Clean and Efficient Energy: Work Programme 2018-2020; EU: Brussels, Belgium, 2018.

85. EU. Horizon 2020 Challenge 10. Secure, Clean and Efficient Energy: Work Programme 2014-2015; EU: Brussels, Belgium, 2015; Volume 2015.

86. Foulds, C.; Christensen, T.H. Funding pathways to a low-carbon transition. Nat. Energy 2016, 1, 1-4. [CrossRef] 